\title{
The HECT E3 Ligase E6AP/UBE3A as a Therapeutic Target in Cancer and Neurological Disorders
}

\author{
Asia Owais ${ }^{1}$, Rama K. Mishra ${ }^{2,3}$ and Hiroaki Kiyokawa ${ }^{1, *}$ \\ 1 Department of Pharmacology, Northwestern University, Chicago, IL 60611, USA; \\ asiaowais2018@u.northwestern.edu \\ 2 Department of Biochemistry and Molecular Genetics, Northwestern University, Chicago, IL 60611, USA; \\ r-mishra@northwestern.edu \\ 3 Center for Molecular Innovation and Drug Discovery, Northwestern University, Evanston, IL 60201, USA \\ * Correspondence: kiyokawa@northwestern.edu
}

Received: 30 June 2020; Accepted: 27 July 2020; Published: 29 July 2020

check for updates

\begin{abstract}
The HECT (Homologous to the E6-AP Carboxyl Terminus)-family protein E6AP (E6-associated protein), encoded by the UBE3A gene, is a multifaceted ubiquitin ligase that controls diverse signaling pathways involved in cancer and neurological disorders. The oncogenic role of E6AP in papillomavirus-induced cancers is well known, with its action to trigger p53 degradation in complex with the E6 viral oncoprotein. However, the roles of E6AP in non-viral cancers remain poorly defined. It is well established that loss-of-function alterations of the UBE3A gene cause Angelman syndrome, a severe neurodevelopmental disorder with autosomal dominant inheritance modified by genomic imprinting on chromosome 15q. Moreover, excess dosage of the UBE3A gene markedly increases the penetrance of autism spectrum disorders, suggesting that the expression level of UBE3A must be regulated tightly within a physiologically tolerated range during brain development. In this review, current the knowledge about the substrates of E6AP-mediated ubiquitination and their functions in cancer and neurological disorders is discussed, alongside with the ongoing efforts to pharmacologically modulate this ubiquitin ligase as a promising therapeutic target.
\end{abstract}

Keywords: ubiquitin; viral oncogenesis; oncoproteins; tumor suppressors; Angelman syndrome; autism; small molecules; imprinting; E3 ligase; chromosome 15q

\section{Introduction and E6AP Structure}

Ubiquitination is a major posttranslational modification which governs the fates of modified protein substrates, i.e., changes in stability, subcellular localization and enzymatic activities [1]. The multi-step process of ubiquitination involves the activation, conjugation and ligation of a ubiquitin moiety mediated by E1, E2, and E3 enzymes, respectively. E3 ligases play crucial roles in recruiting substrates and they primarily determine substrate specificity [1]. Aberrant regulation of E3 ligases disrupts diverse cellular functions such as cell cycle control, DNA damage response and cell death, and could shift the balance towards oncogenesis [2]. The human genome encodes more than $600 \mathrm{E} 3$ ligases, which are classified into a few major families based on their structural similarities: RING (Really Interesting New Gene), RBR (ring between ring), Ubox and HECT E3 ligases [3]. In this review, we focus on one of the HECT E3 ligases, E6AP, which is also known as UBE3A and plays roles in oncogenesis, neurodevelopmental disorders, and other human diseases [4].

HECT-E3s ubiquitinate their specific substrate in a two-step process. First, an HECT-E3 binds to an E2 in complex with activated ubiquitin, leading to the formation of a thioester linkage between the C-terminus of ubiquitin and the catalytic cysteine residue in the HECT domain. This transient complex subsequently transfers ubiquitin to an interacting substrate with the formation of an isopeptide bond [5]. 
Structurally, E6AP possesses a $\mathrm{Zn}^{2+}$-binding N-terminal (Amino-terminal Zn-finger of Ube3a Ligase (AZUL)) domain and a catalytic HECT domain of $~ 350$ amino acids at the $C$ terminus (Figure 1a) [6]. A domain necessary for binding with the human papillomavirus (HPV) E6 oncoprotein is located between the AZUL and HECT domains [7]. The AZUL domain is involved in substrate recruitment and also self-inhibitory regulation [8]. Most mutations associated with the neurodevelopmental disorder Angelman syndrome (AS) are found in the HECT domain, indicating that the loss of catalytic function of E6AP causes AS [9]. Considering the human E6AP-UBCH7 complex crystal structure (1C4Z.pdb) [6], we have extracted out the E6AP part by the Biopolymer module implemented in Tripos software and highlighted AS-associated mutations and the catalytic Cys820 residue (Figure 1b). The $\mathrm{N}$ lobe (labeled in magenta) binds to the specific E2 partner, UBE2L3/UbcH7. Many AS mutation sites are located in the areas on both the C lobe (labeled in green) and N lobe surrounding Cys820, while some mutations are found in the E2-binding region of the N lobe, e.g., Thr656 and Phe690 [10]. AS-linked missense mutations have also been reported in the AZUL domain [9,11], suggesting the significance of the domain in catalytic regulation. Aside from its ubiquitin ligase function, E6AP also acts as a transcriptional co-activator of steroid hormone receptors such as estrogen, progesterone and androgen receptors (ER, PR and AR, respectively) $[4,12,13]$. E6AP contains a nuclear localization signal that allows it to be localized to the nucleus, and three LxxL motifs, which are important for receptor interaction $[4,14,15]$. The transactivating function of E6AP has been mapped to a region outside the HECT domain (residues 170-680) [4].

Recent evidence suggests that E6AP exists in two conformational states of high and low activity. While the potent activation of E6AP by E6 binding is well known, the binding with HERC2, another HECT E3, also stimulates the activity of E6AP (Figure 1a) [16,17]. Mutations in HERC2 which cause degradation of HERC2 have been associated with an AS-like syndrome. Furthermore, protein kinase A-mediated phosphorylation of Thr485, which is located outside the HECT domain, inhibits E6AP activity. An autism-linked missense mutation that disrupts this phosphorylation site causes enhanced E6AP activity [18].

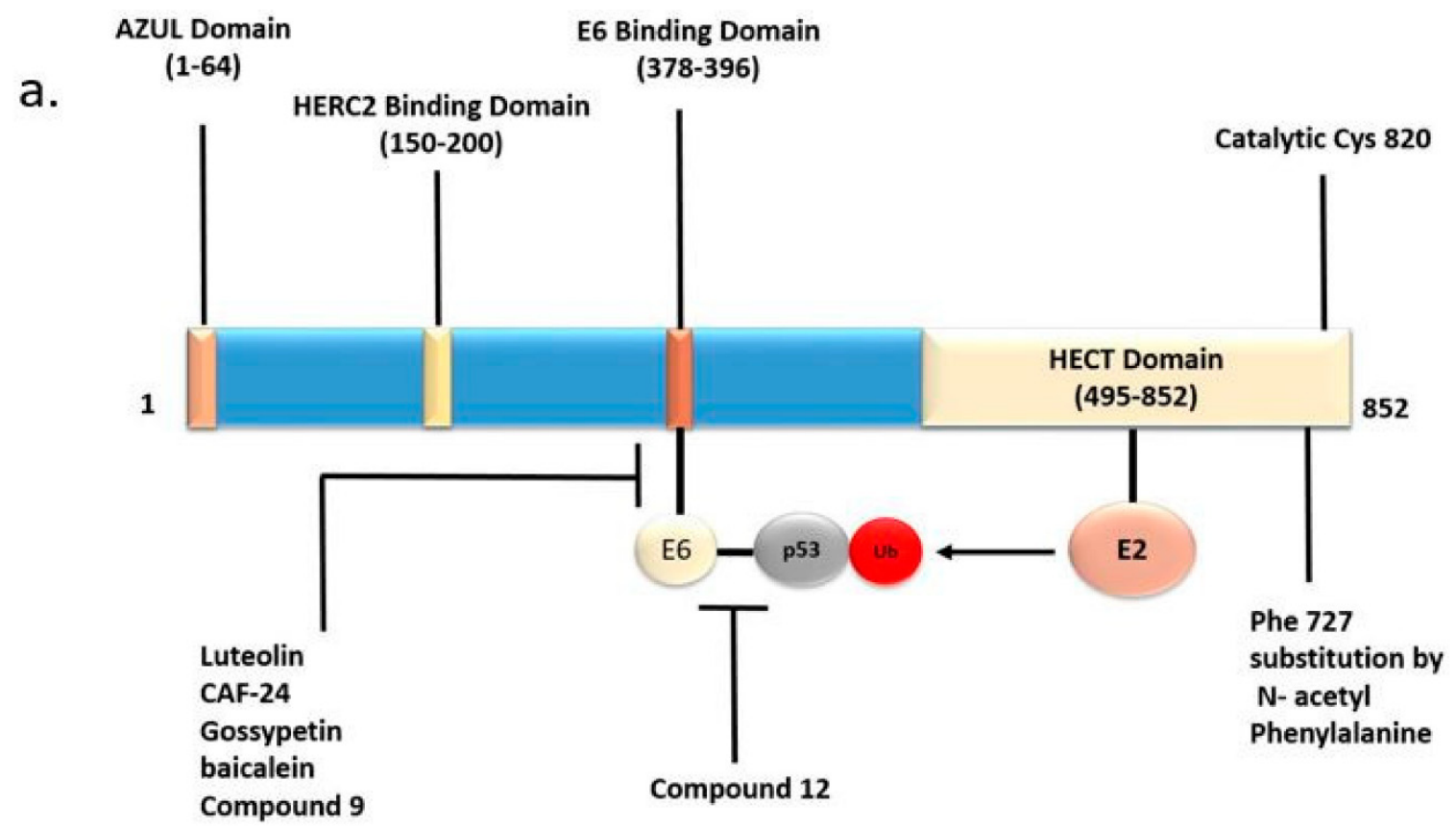

Figure 1. Cont. 
b.

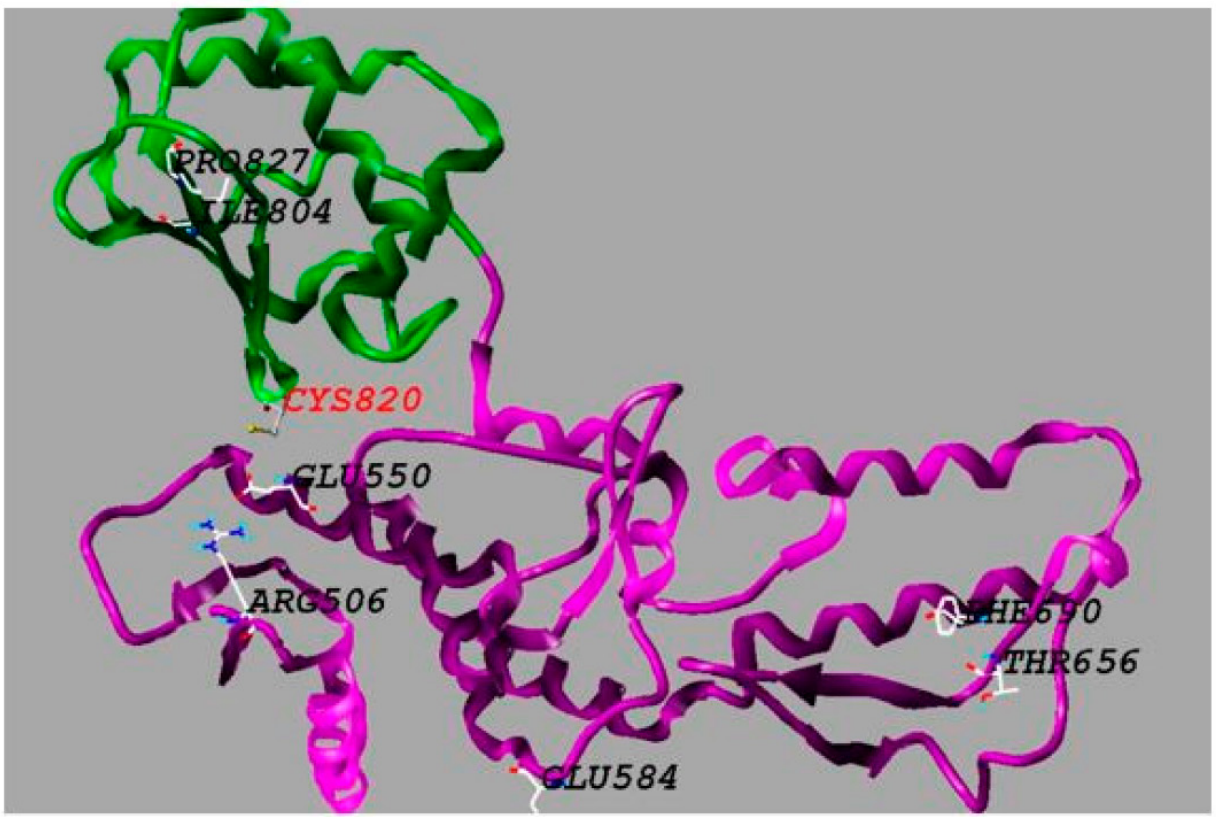

Figure 1. E6AP domains and their therapeutic significance. (a) Domains in the primary sequence of E6AP protein. The numbers in parentheses indicate the corresponding amino acid residues of E6AP isoform 1 protein. The C-terminus of E6AP protein has the prototype Homologous to the E6-AP Carboxyl Terminus (HECT) domain. This domain has the E2-binding site and the catalytic center Cys820. E6-binding domain binds the HPV E6 oncoprotein. The Zn-binding Amino-terminal Zn-finger of Ube3a Ligase (AZUL) domain is present at the $\mathrm{N}$ terminus. The HERC2-binding domain is required for the association with the partner HECT E3 HERC2. Small molecule inhibitors targeting the E6AP-E6 and E6-p53 interactions that disrupt the E6AP-E6-p53 complex are potential therapeutic strategies for human papillomavirus (HPV). Substitution of Phe727 by N-acetyl phenylalanine inhibits the oligomerization of E6AP essential for its activity. (b) Crystal structure of the HECT domain and the locations of Angelman syndrome (AS)-linked missense mutations. The $\mathrm{N}$ lobe is colored in magenta and the $\mathrm{C}$ lobe is colored in green. The catalytic Cys820 is labeled in red. Hereditary and de novo missense mutations found in the indicated amino acids are thought to be pathogenic in AS patients. The Biopolymer module of Tripos software was used to generate the figure, considering the E6AP part of $1 \mathrm{C} 4 \mathrm{z}$.pdb crystal structure.

\section{E6AP in Cancer}

The discovery of E6AP lends itself to the seminal finding that the human papillomavirus (HPV) oncoprotein E6 mediates degradation of the tumor suppressor protein p53 by activating this E3 [19], which is a classic example of the downregulation of tumor suppressors by viral oncoproteins. E6AP has been studied for its involvement in not only viral oncogenesis but also non-viral oncogenesis [20-23], as recently reviewed by Bandilovska et al. [24]. Here, we focus on the roles of diverse targets of E6AP in various cancers, as summarized in Table 1.

\subsection{HPV-Associated Cancers}

HPV induces a variety of human cancers such as cervical and head and neck cancers. The involvement of E6AP in viral oncogenesis was first established in HPV-associated cervical cancer $[19,25]$. The HPV oncoprotein E6 hijacks the E3 activity of E6AP by acting as an allosteric activator, and mediates polyubiquitination and the subsequent proteasomal degradation of p53 [19,26]. On the other hand, the HPV oncoprotein E7 binds to the tumor suppressor retinoblastoma protein $(\mathrm{Rb})$ and converts the associated E2F transcription factors from repressors to transactivators [27]. Thus, HPV infection effectively targets the two major tumor suppressors p53 and Rb in epithelial cells, leading to malignant transformation and cancer development. 


\subsection{HCV-Associated Cancers}

Chronic inflammation from hepatitis $\mathrm{C}$ virus (HCV) infection leads to hepatocellular carcinoma [28]. E6AP promotes $\mathrm{HCV}$-induced oncogenesis by mediating the proteasomal degradation of $\mathrm{Rb}$ protein. The RNA-dependent RNA polymerase of $\mathrm{HCV}$, non-structural protein $5 \mathrm{~B}$ (NS5B), sequesters Rb in the cytoplasm where E6AP ubiquitinates and degrades $\mathrm{Rb}$ [29]. E6AP also plays a role in antiviral defense by ubiquitinating and degrading a core $\mathrm{HCV}$ protein [30]. In turn, HCV suppresses E6AP expression by DNA methylation [31]. Thus, E6AP appears to activate antiviral defense, while it promotes oncogenic transformation induced by HCV.

\subsection{Cancers Associated with PML Downregulation}

The tumor suppressor promyelocytic leukemia protein (PML) has been identified as a ubiquitination target of E6AP. E6AP-mediated degradation of PML promotes tumorigenesis in multiple types of cancer (Figure 2) [20,32]. PML was first identified as a gene fused with the retinoic acid receptor $(R A R)$ gene in acute promyelocytic leukemia patients with $(15 ; 17)$ chromosomal translocation. The fusion gene product suppresses the wild type tumor suppressor PML in a dominant negative fashion $[33,34]$. Furthermore, perturbed regulation of PML has been found in a variety of cancers without chromosomal translocations [35]. PML forms distinct structures in the nucleoplasm called the PML-nuclear body (NB). PML-NB mediates post-translational modifications of a variety of proteins, most notably conjugation with the ubiquitin-like protein Small Ubiquitin Like Modifiers (SUMO) [36]. The PML-NB clients regulate diverse cellular processes including gene transcription, DNA repair, apoptosis, senescence, and anti-viral response (Figure 2) [32-35,37-50]. Among the well-studied downstream effectors of PML are p53, Rb, signal transducer and activator of transcription 3 (STAT3) and integrin subunit beta 1 (ITGB1) $[38,44,47,49,50]$.

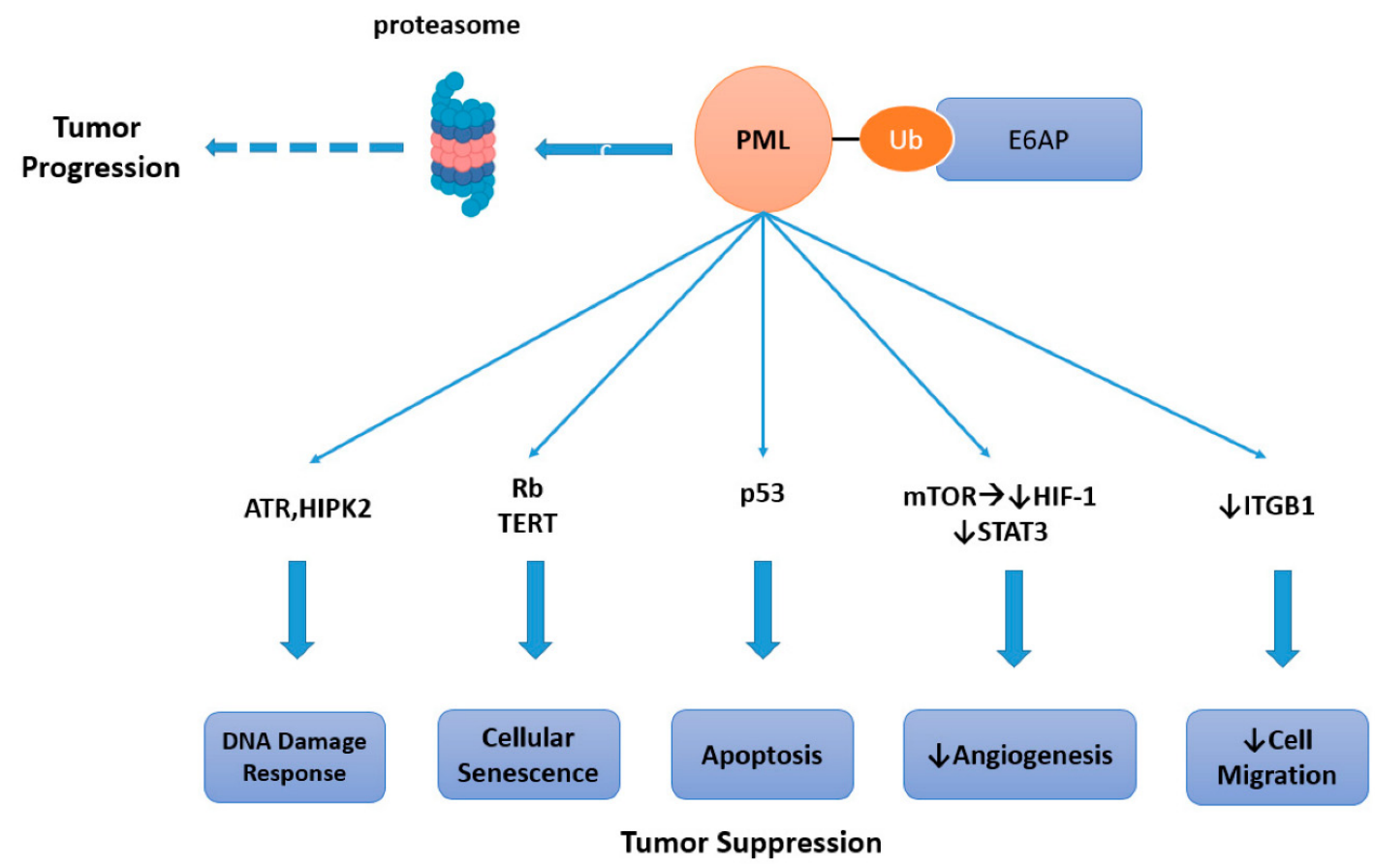

Figure 2. E6AP ubiquitinates promyelocytic leukemia protein (PML) and leads to tumor progression. PML causes tumor suppression by regulating cellular apoptosis [38], DNA damage response [42] and cellular senescence [46,50]. It inhibits angiogenesis and cell migration [37,44,49]. E6AP-mediated ubiquitination of PML leads to its proteasomal degradation and promotes tumorigenesis [38]. ATR-Ataxia telangiectasia and Rad3-related protein kinase, HIPK2-Homeodomain Interacting Protein Kinase 2, TERT- telomerase reverse transcriptase, mTOR-mammalian target of rapamycin, HIF-1-hypoxia inducible factor. 


\subsubsection{Burkitt's Lymphoma}

Hyperactivation of the E3 ligase activity of E6AP is evident in Epstein-Barr virus-associated Burkitt's lymphoma. Approximately $60 \%$ of Burkitt's lymphomas show downregulation of PML expression correlated with high levels of E6AP [20]. Hemizygous disruption of the Ube3a gene can attenuate murine B-cell lymphomagenesis driven by the $\mathrm{E} \mu$ (immunoglobulin enhancer)-Myc transgene with concomitant upregulation of PML [20], recapitulating the oncogenic role of E6AP in Burkitt's lymphoma.

\subsubsection{Prostate Cancer}

E6AP functions as a transcriptional co-activator of AR, and plays an oncogenic role in prostate glands $[4,51]$. E6AP expression is upregulated in a subset of prostate cancers. The oncogenic role of E6AP in prostate cancer is also associated with ubiquitin-dependent degradation of the tumor suppressor proteins PML and p2 $7^{\mathrm{Kip} 1}$, which is characteristic in aggressive and late stages of prostate cancer [21,52]. A recent study that evaluated the transcriptome-and proteome-wide effects of E6AP knockdown identified new transcriptional and posttranscriptional targets of E6AP in prostate cancer [53]. Among the targets negatively regulated by E6AP is the stress-induced chaperone clusterin (CLU), which may play a tumor-suppressive role in prostate cancer.

\subsection{Non-Small Cell Lung Cancer}

In non-small cell lung cancer (NSCLC), E6AP may exert a tumor suppressive function [22]. E6AP expression is decreased in $\sim 20 \%$ of NSCLC tissues, which correlates with lower levels of the cyclin-dependent kinase (CDK) inhibitor p16 ${ }^{\mathrm{INK} 4 \mathrm{~A}}$. E6AP binds to the transcription factor E2F1 as a co-factor, repressing the expression of CDC6, a key transcriptional repressor of the INK4/ARF locus encoding $\mathrm{p} 16^{\mathrm{INK} 4 \mathrm{~A}}$ and $\mathrm{p} 14^{\mathrm{ARF}}$. Therefore, downregulation of E6AP in NSCLC results in the decrease in p16 ${ }^{\mathrm{INK} 4 \mathrm{~A}}$ expression. NSCLC patients with the characteristic of E6AP-low/CDC6-high/p16-low exhibit reduced overall survival. Furthermore, this characteristic is associated also with KRAS mutations in lung adenocarcinomas, implying a prognostic value of E6AP-low/CDC6-high/p16-low in the adenocarcinoma subtype of NSCLC [22].

\subsection{Breast Cancer}

E6AP acts as a transcriptional co-activator, promoting the transactivation by ER- $\alpha$ and PR, as well as AR [4]. E6AP could also ubiquitinate ER- $\alpha$ to target the receptor to proteasomal degradation [23]. In breast cancer, E6AP appears to play conflicting roles in promoting or suppressing cancer progression, which may be associated with its dual functions. E6AP expression is modestly downregulated in human invasive breast cancers, correlated with increased expression of ER- $\alpha$ and poorer prognosis of patients $[23,54]$. Transgenic mice that overexpress wild-type E6AP in mammary tissues fail to display any appreciable changes in morphology, while mice expressing a ligase-defective E6AP mutant develop mammary hyperplasia with concomitant upregulation of ER- $\alpha$ and PR [54]. These data suggest that, in mammary tissues, the E3 ligase activity of E6AP mostly plays a tumor-suppressive role by triggering degradation of the oncogenic drivers ER- $\alpha$ and PR, and this action of E6AP overshadows its potential oncogenic action as a co-activator. The significance of the control of ER- $\alpha$ levels at the degradation step is supported by another study showing that E6AP and calmodulin reciprocally control the stability of ER- $\alpha$ protein [55]. Breast cancer cell lines treated with a calmodulin antagonist, CGS9343B, show enhanced binding of E6AP to ER- $\alpha$ and accelerated degradation of the receptor [55]. In addition to the steroid receptors, a few breast-cancer-related oncoproteins have been identified to be substrates of E6AP-mediated ubiquitination. The steroid receptor co-activator oncogene AIB1 (amplified in breast cancer 1) is amplified and overexpressed in breast cancer [56-58]. Increased AIB1 expression is correlated with poor prognosis [59-61]. E6AP ubiquitinates and degrades AIB1 in breast cancer cell lines [62]. E6AP also ubiquitinates and degrades Enolase1 (ENO1), a glycolytic enzyme [63]. 
ENO1 expression is increased in breast cancer [64], which is likely to play a role in cancer-specific alterations in energy metabolism, i.e., Warburg effects, and also in metastasis via enzymatic degradation of extracellular matrix $[65,66]$.

Table 1. E6AP Substrates in Cancer.

\begin{tabular}{cccc}
\hline E6AP Substrate & Associated Disorder & Biological Role & References \\
\hline PML & $\begin{array}{c}\text { Burkitt's Lymphoma, } \\
\text { Prostate Cancer }\end{array}$ & $\begin{array}{c}\text { Tumor suppressor, controls numerous proteins in PML-NB, } \\
\text { induces cellular senescence }\end{array}$ & {$[20,32]$} \\
\hline p27 & Prostate Cancer & $\begin{array}{c}\text { Cyclin-dependent kinase inhibitor, prevents progression } \\
\text { from } \mathrm{G}_{1} \text { to S phase }\end{array}$ & {$[21,67]$} \\
\hline E2F1 & NSCLC & $\begin{array}{c}\text { Transcription factor, transactivates cell cycle genes including } \\
\text { CDC6, whose product represses the INK4/ARF locus }\end{array}$ & {$[22]$} \\
\hline ER- $\alpha$, PR & Breast Cancer & $\begin{array}{c}\text { Steroid receptors/transcription factors, drive expression of } \\
\text { proliferative genes }\end{array}$ & {$[13]$} \\
\hline ENO1 & Breast Cancer & Metabolic enzyme, controls energy metabolism and \\
extracellular matrix degradation & {$[63]$} \\
\hline AIBI & Breast Cancer & Oncoprotein, transcriptional co-activator of ER. & {$[57]$} \\
\hline p53 & HPV related cancers & Tumor suppressor, induces growth arrest and apoptosis & {$[19,68]$} \\
\hline Clusterin & Prostate Cancer & Stress induced chaperone protein, tumor suppressor & {$[53]$} \\
\hline HHR23A/RAD23A & Breast, Lung Cancer & Nucleotide excision repair protein & {$[69]$} \\
\hline
\end{tabular}

\section{E6AP in Neurological Disorders}

E6AP/UBE3A is widely known for its involvement in neurodevelopmental disorders. Genetic alterations in the UBE3A locus are linked with AS and chromosome 15q11.2-q13.3 duplication syndrome (Dup15q) [70]. Identifying the neuronal substrates of E6AP is important to elucidate the mechanism of neurological deficits in these disorders and develop effective treatments. Table 2 summarizes the E6AP targets that have been associated with neurological disorders.

\subsection{Genetic Alterations in AS and ASD}

$U B E 3 A$ gene dosage is critical for neuronal development. Loss of neuronal UBE3A expression results in AS, while increased dosage of the gene is associated tightly with autism spectrum disorders (ASD) (Figure 3). The UBE3A locus on chromosome region 15q11-q13.1 is paternally imprinted in neurons $[70,71]$. This is mediated at least partly by an antisense transcript UBE3A-ATS, which is paternally expressed and silences UBE3A expression (Figure 4) [72]. Consequently, UBE3A is expressed only from the maternal allele in normal neurons, and the loss of maternal UBE3A expression causes AS, which is characterized by a cheerful demeanor, developmental delay, impaired speech and seizures. On the other hand, increased copy numbers of $U B E 3 A$ due to Dup15q markedly increase the penetrance of ASD [73] (Figure 3).

\subsection{Role of E6AP in Neuron Morphology, Synaptic Plasticity and Excitability}

E6AP orchestrates a broad range of effects on neuron morphology and functions. Abnormalities in neuron morphology are evident in AS. Abnormal dendritic spine length and polarization have been reported in AS model mice [74,75]. X-linked inhibitor of apoptosis (XIAP) has been recently identified as an E6AP target. XIAP is required for proper dendritic arborization. ASD-model transgenic mice overexpressing E6AP in neurons exhibit lower expression of neuronal XIAP, leading to caspase activation, microtubule degradation, and impaired spine maturation with less branching [76]. Learning and memory deficits are characteristic of AS. Altered synaptic plasticity and long-term potentiation (LTP) defects in hippocampal neurons have been found in AS model mice [77]. Decreased synaptic plasticity is observed in the visual cortex of mice with monocular deprivation [78,79]. The activity-regulated, cytoskeleton-associated protein (ARC), an E6AP target, controls synaptic function by promoting the internalization of $\alpha$-amino-3-hydroxy-5-methyl-4-isoxazolepropionic 
acid (AMPA) receptors. Loss of E6AP expression in AS neurons results in an increase in ARC expression and a concomitant decrease in synaptic AMPA receptors, implying a mechanism of synaptic dysfunction in AS [80]. However, it is controversial whether ARC is actually a direct substrate of E6AP. Another suggested mechanism is that E6AP negatively regulates ARC at the transcriptional level [81]

Typical

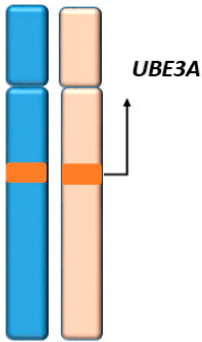

Pat. Mat.
Angelman Syndrome

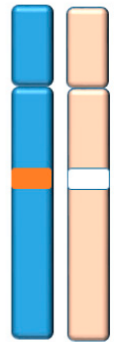

Deletion

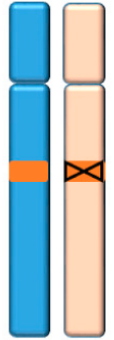

Mutation

Dup 15q Syndrome

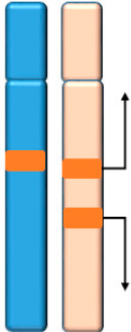

\section{Maternal}

Insterstitial

Duplication

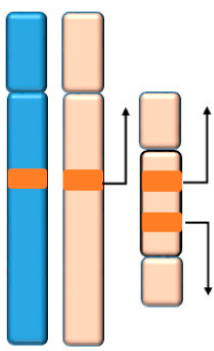

Isodicentric Chromosome 15

Figure 3. Genetic alterations in $U B E 3 A$ locus. The $U B E 3 A$ gene is located in chromosome 15 region q11.2-q13. Typically, only the maternal copy is expressed while the paternal copy is silenced in neurons. In Angelman syndrome (AS), the maternal allele is deleted or mutated. Multiple copies of $U B E 3 A$ are expressed in Dup15q syndrome, which is characterized by autism spectrum disorder (ASD) phenotypes.

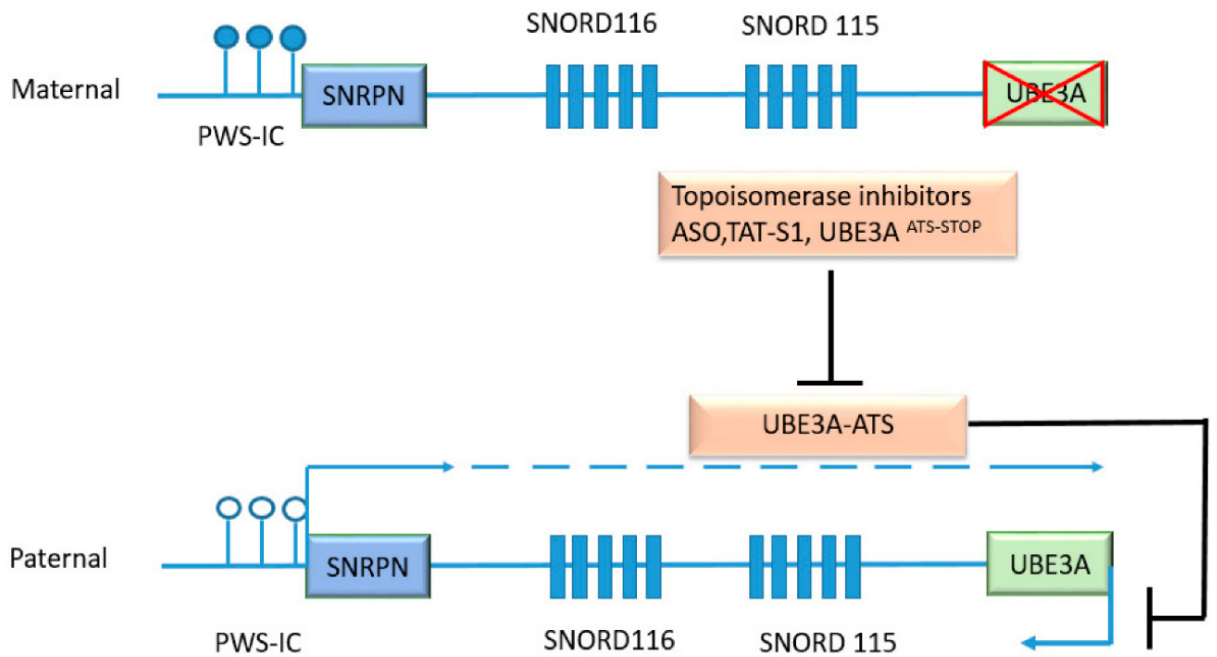

Figure 4. UBE3A-ATS as a mediator of genomic imprinting in neurons and as a therapeutic target. UBE3A-ATS is a large transcript which initiates at the Prader-Willi syndrome imprinting center (PWS-IC). The PWS-IC is not methylated (clear circles) in the paternal allele and allows the initiation of transcription. The progression of transcription through UBE3A-ATS locus is responsible for the paternal imprinting of UBE3A in neurons. UBE3A-ATS includes the protein-coding gene SNRPN and genes encoding small nucleolar RNAs SNORD 116 and SNORD 115. Targeting UBE3A-ATS by topoisomerase inhibitors, antisense oligonucleotides, artificial transcription repressor TAT-S1, or insertion of stop codon $U B E 3 A^{\text {ATS-STOP }}$ could restore UBE3A expression in AS neurons. The maternal PWS-IC is methylated (dark circles) and the expression of UBE3A-AS is silenced.

The Small Conductance Potassium Channel (SK2) is also important for the induction of LTP and synaptic plasticity. SK2 has been shown to undergo E6AP-mediated ubiquitination. In response to N-methyl-D-aspartate (NMDA) receptor activation, SK2 channels are activated. E6AP ubiquitinates SK2 to promote internalization of the channel. UBE3A-deficient AS model mice show higher levels 
of SK2 in the hippocampal neurons and decreased synaptic plasticity [82]. Ephexin V, an established substrate of E6AP, is a guanine nucleotide exchange factor (GEF) which activates RhoA. Degradation of Ephexin V promotes excitatory synapse development. Elevated levels of Ephexin V in AS neurons may lead to defective synapse formation and cognitive impairment [83]. Epilepsy is present in $85 \%$ of AS patients [84]. Altered excitatory/inhibitory balance has been reported in AS model mice which display increased susceptibility to seizures $[85,86]$. Decreased GABA-ergic inhibitory input has been found in UBE3A-deficient AS model mice [87], and treatment with GABA agonists reduces the seizure susceptibility in those mice [88]. However, the E6AP targets that play key roles in controlling GABA signaling remain to be determined.

Sleep disturbances are reported in 75\% of AS patients [89]. Brain and Muscle ARNT-Like 1 (BMAL1) is a clock protein critical to maintaining the circadian clock, and is a substrate of E6AP-mediated ubiquitination [90]. UBE3A-deficient mice have elevated levels of BMAL1 accompanied by impaired circadian rhythm [91].

It has been demonstrated that E6AP activates the Wnt signaling pathway with stabilization of $\beta$-catenin [92]. Wnt signaling is critical for normal development and is implicated in the pathogenesis of ASD [93,94]. TSC2, a negative regulator of mammalian target of rapamycin (mTOR), has been shown to be a E6AP substrate [95]. mTOR dysregulation has been described in AS and ASD [96].

Among the targets of E6AP that are controlled at the transcriptional level are the E3 ligase Ring1B [97]. It interacts with the polycomb group repressor complex and ubiquitinates histone H2A to impact on global gene expression. UBE3A-deficient mice exhibit increased levels of Ring1B and H2A in cerebellar purkinje neurons, suggesting its involvement in the development of AS neuronal deficits.

E6AP also activates the transcription of the ESR2 gene encoding ER- $\beta$ [98]. ESR2 is involved in brain development, while it also plays a neuroprotective role against neurodegenerative insults. The role of ESR2 in the development and progression of Alzheimer's disease (AD) has been well accepted $[99,100]$. ESR2 is important for synaptic plasticity and LTP via its regulation of brain-derived neurotrophic factor (BDNF) [101,102]. Overexpression of ESR2 in a rat model of AD reduced amyloid- $\beta$ deposition in the hippocampus and improved the learning and memory of AD rats [99].

$26 \mathrm{~S}$ subunit, non-ATPase 4 (PSMD4), is a subunit of the $26 \mathrm{~S}$ proteasome and an E6AP substrate [103]. The ubiquitination and degradation of PSMD4 may hamper proteasomal degradation of many cellular proteins and exert broad-spectrum effects on the proteostasis in neurons. A recent study showed that PSMD4 binds to the AZUL domain of E6AP and is necessary for its nuclear localization. This study suggested the nuclear form of E6AP plays an important role in neurodevelopment [104].

$\mathrm{Xu}$ et al., identified ALDH1A2, the rate-limiting enzyme of retinoic acid synthesis to be negatively regulated by E6AP. RA-mediated synaptic plasticity is altered with excessive UBE3A dosage. Administration of an RA antagonist or overexpression of UBE3A recapitulated the synaptic defects in ASD, while these defects were rescued by administration of RA [105].

A recent study identified phosphotyrosyl phosphatase activator (PTPA), an activator of protein phosphatase 2A (PP2A), as a substrate of E6AP-mediated ubiquitination [106]. Neurons in the AS model mice exhibit increases in PTPA levels and PP2A activity. Hemizygous knockout of the Ptpa gene or pharmacological inhibition of PP2A can ameliorate the defects in dendritic spine maturation of the AS model neurons, suggesting the significance of the E6AP-PTPA-PP2A pathway in AS pathophysiology.

Table 2. E6AP Substrates in Neurological Disorders.

\begin{tabular}{ccccc}
\hline Substrates & $\begin{array}{c}\text { Associated } \\
\text { Neurological Disorder }\end{array}$ & Biological Role & References \\
\hline ARC & AS & $\begin{array}{c}\text { Causes internalization of AMPA receptors at synapse. } \\
\text { Important for synaptic plasticity }\end{array}$ & [80,81,107,108] \\
\hline BMAL1 & Tuberous Sclerosis & $\begin{array}{c}\text { A clock protein critical to maintain the circadian clock under } \\
\text { the control by the mTOR pathway }\end{array}$ & [90] \\
\hline TSC2 & Tuberous Sclerosis & Negative regulator of mTOR pathway, tumor suppressor. & [95,96] \\
\hline Ring1B & AS & Ubiquitinates histone H2A. May affect global gene expression & [97] \\
\hline
\end{tabular}


Table 2. Cont.

\begin{tabular}{ccccc}
\hline Substrates & $\begin{array}{c}\text { Associated } \\
\text { Neurological Disorder }\end{array}$ & Biological Role & References \\
\hline ESR2/ER- $\beta$ & Alzheimer's Disease & Increase LTP and enhances synaptic strength & [98,109,110] \\
\hline Ephexin V & AS & RhoA GEF, important for excitatory synapse development & [83] \\
\hline Peroxiredoxin1 & Alzheimer's Disease & Antioxidant enzyme, protects from oxidative damage & [111-115] \\
\hline SK2 & AS, ASD & LTP and synaptic plasticity & [82,116] \\
\hline XIAP & ASD & $\begin{array}{c}\text { Required for dendritic arborization, suppresses caspase } \\
\text { activation and microtubule degradation }\end{array}$ & [76,117-119] \\
\hline PSMD4 & AS & $\begin{array}{c}\text { Subunit of 26S proteasome, controls global proteostasis. } \\
\text { Interacts with the AZUL domain of UBE3A }\end{array}$ & [103] \\
\hline AL-catenin & ASD, AS & Transcription factor and canonical mediator of Wnt signaling & [92] \\
\hline P18 & ASD & Rate limiting enzyme in RA synthesis & [120] \\
\hline PTPA & ASD & Subunit of Ragulator complex & A106] \\
\hline
\end{tabular}

\section{Therapeutic Approaches to Target E6AP and Downstream Effectors}

\subsection{Challenges in Identifying HECT E3 Inhibitors}

HECT E3 ligases are attractive therapeutic targets because of their involvement in a variety of human diseases. However, the efforts to develop small molecule inhibitors of HECT E3s are still in their infancy. The complexity of ubiquitination reactions and weak interactions between E3s and their substrates pose a challenge in identifying inhibitors of HECT E3s by high-throughput screens [121,122]. Small molecule screens have been performed successfully for classical targets such as kinases, proteases, G-protein coupled receptors (GPCRs), ion channels, and nuclear receptors, which typically possess well-defined small-molecule binding pockets. Several small-molecule inhibitors of RBR and RING E3 ligases have been published, including the inhibitors of HOIP, VHL, WWP2 and RNF4 [123-129]. However, small-molecule binding pockets in HECT E3s have been poorly defined. Detailed analysis of three-dimensional structures of the HECT domain and mutational analyses will facilitate the development of high-affinity, small-molecule modulators. Here, therapeutic strategies specific to E6AP are discussed, targeting its E3 ligase and co-activator functions.

\subsection{Therapeutic Strategies for HPV-Induced Cancers}

HPV-induced cancers are still highly prevalent. Although the HPV vaccines have been widely introduced, it will take decades for their preventive effects against cancers to become dominant. Thus, target-based therapies against HPV-induced cancers are still in critical need. Disruption of the E6AP-E6-p53 complex serves as an attractive therapeutic target, as it would ultimately re-activate p53, leading to growth arrest and apoptosis of HPV-transformed cells.

The crystal structure of E6AP-E6-p53 ternary complex was identified by Zapien et al. [130]. This structure provides a framework for the design of inhibitory therapeutic strategies against E6-E6AP and E6-p53 interfaces (Figure 1a). A recent study demonstrated that the binding with E6 causes a conformational change in E6AP structure, which facilitates the binding of p53 in close proximity to the catalytic center of E6AP [131], providing further insight into the mechanism of E6AP activation. There have been multiple small molecule approaches for targeting the E6-p53 and E6AP-E6 interfaces as well as for inhibiting the E3 ligase activity of E6AP, as discussed below.

Mutagenesis of critical residues at the E6-p53 interface abrogates p53 degradation. According to the structural model, p53 is bound on a cleft spanning both the N-terminal and C-terminal domains of E6 [130]. N-terminal residues of E6 that are located in the central region of the p53-binding cleft, i.e., Asp44, Phe47 and Asp49, play a critical role in this interaction and are highly conserved among high-risk mucosal HPV genotypes [130]. Given the importance of this region in HPV-induced oncogenesis, this interface has become an attractive target for small molecule 
development. Compound 12 has been identified as an inhibitor of the E6-p53 interaction that can reduce the viability and proliferation of HPV-positive cells [132].

The LxxLL-containing alpha helix of E6AP within the HECT domain binds to a hydrophobic binding groove in E6 [133]. This binding pocket offers a favorable niche for small molecules. Flavanoid compounds, Luteolin and CAF024, which mimic leucines in the conserved alpha helical motif of E6AP have been found to inhibit the E6-E6AP interaction [134]. Molecular modelling and simulation studies have revealed some additional inhibitors of the E6-E6AP interaction [135]. It has been demonstrated that the space between the two Zinc finger domains of E6 constitutes the LxxLL binding pocket [136]. Beerheide et al., identified compounds that eject $\mathrm{Zn}$ specifically from $\mathrm{E} 6$ and disrupt the E6-E6AP interaction. One such compound, 4,4'-dithiodimorpholine, reduced the viability of tumorigenic HPV cells with p53 upregulation.

Other approaches to inhibit E6 activity include peptides that interact with the E6AP-binding groove [137]. Intracellular antibodies or "Intrabodies" have also been shown to inhibit the growth of HPV-positive cancer cells [138]. However, the large size and complex structure of intracellular antibodies is a limitation in successful drug development [139].

Biochemical and structural analyses of E6AP have shown that the fully active form of E6AP is a trimer, and E6 oncoprotein promotes the trimerization. The interaction between the Phe727 residue in the HECT domain of E6AP and a hydrophobic pocket of E6 is critical to the formation of this trimer. $\mathrm{N}$-acetyl phenylalanine blocks E6AP trimerization by substituting Phe727 and inhibits its E3 activity at a high concentration $(\mathrm{Ki}=12 \mathrm{mM})$ [8]. Another approach using compounds mimicking natural products to inhibit the E3 ligase activity of E6AP has been described. Macrocyclic N-methyl peptide inhibitor, CM11-1, can inhibit E6AP activity to catalyze ubiquitination of Prx1 and p53 [9].

\subsection{Targeting UBE3A in Neurodevelopmental Disorders}

Current therapies for AS are only directed toward mitigating symptoms, such as anti-seizure medications and physical therapies. There have been multiple approaches to develop mechanism-based therapies for AS (Figure 4).

\subsubsection{Approaches to Target UBE3A-ATS}

Efforts have been ongoing to reverse the paternal silencing of $U B E 3 A$ in AS with mutations or deletions on the maternal allele. Several topoisomerase inhibitors, including topotecan, have been demonstrated to inhibit the transcription of the nuclear-localized long non-coding RNA Ube3A-ATS and allow the expression of $U B E 3 A$ from the paternal allele [140]. Although the pleiotropic effects of topotecan that inhibit the transcription of many other synaptic genes is a concern [141,142], the observed effects of topoisomerase inhibitors on $U B E 3 A$ regulation are encouraging for the future development of drugs that can unleash expression of the imprinted UBE3A allele.

Antisense oligonucleotides (ASO) offer an approach for gene therapies with high specificity, while the delivery of nucleotides remains challenging. ASO targeting Ube3a-ATS can effectively unsilence the paternal UBE3A allele in neurons, and ameliorate some cognitive deficits (e.g., "freezing") in AS model mice. However, the ASO shows no effects on other behavioral defects [143]. Recently, the FDA granted the Orphan Drug designation for the UBE3A-ATS-targeting oligonucleotides to facilitate drug development.

An alternate approach to unsilence the paternal allele was to provide dietary supplements of methionine to increase methylation, thereby repressing the transcript which includes UBE3A ATS. However, two clinical trials with methionine supplementation reported no significant difference in the clinical outcome between the control and the treatment groups [144,145]. Forced activation of the $U B E 3 A$ promoter or repression of UBE3A-ATS using artificial transcription factors is another feasible strategy. An artificial transcription factor, TAT-S1, which represses the locus encoding UBE3A-ATS, has been shown to increase Ube3a expression throughout the brain of AS model mice [146]. 


\subsubsection{Therapeutic Interventions of Downstream Effectors}

Several experimental studies evaluated the effects of therapeutic interventions of effectors downstream of UBE3A in AS models. Reducing the expression levels of ARC alleviated audiogenic seizures in Ube3a-deficient mice, whereas there were no observed changes in motor deficit or ultrasonic vocalizations [108]. Excessive inhibitory phosphorylation of calmodulin-dependent protein kinase II (CAMKII) has been implicated for impaired synaptic plasticity in AS [147]. Levodopa can prevent the CAMKII phosphorylation and reduce the seizure propensity and deficits in motor performance, hippocampal learning and plasticity in the AS model mice [148]. A clinical trial of Levodopa for AS is on-going, and its data are awaited (NCT01281475). Ampakines, the modulators of AMPA receptors, have been shown to increase BDNF release and improve hippocampus-dependent learning behavior in AS model mice, suggesting their potential to alleviate LTP in AS. Blocking SK2 channels may also improve LTP, memory and learning behavior and restored activity dependent on actin polymerization. Systemic injection of a SK2 channel blocker has been shown to restore fear conditioning in the AS model $[82,116,149]$. The significance of the mTOR pathway in brain development and synaptic plasticity has been well established $[96,150]$. Hyperactivation of mTORC1 and hypoactivation of mTORC2 in UBE3A-deficient mice is apparently associated with motor dysfunction and deficits in LTP, fear conditioning and memory, which could be restored by the mTORC1 inhibitor Rapamycin as well as the mTORC2 activator A-443654 [151].

It has been shown that E6AP regulates mTORC1 signaling by targeting p18, a subunit of the Ragulator complex [120]. Hyperactivation of mTORC1 is also observed in ASD associated with mutations in genes upstream of mTOR, e.g., tuberous sclerosis complex (TSC), fragile $X$ syndrome, and neurofibromatosis. Rapamycin has been shown to be effective for ASD associated with PTEN mutations, as well as for the ASD model mice [150,152].

\section{Concluding Remarks}

Therapeutic targeting of E3 ligases requires a multi-faceted approach including comprehensive profiling of the ubiquitination substrates, thorough analyses of the enzyme structures and efficient development of small molecule modulators. In this review, we have discussed the roles of E6AP/UBE3A in the pathophysiology of cancers and neurodevelopmental disorders, and highlighted the E6AP-substrate interactions and downstream pathways that could be therapeutic targets. With the development of novel substrate profiling technologies such as Orthogonal Ubiquitin Transfer [153], more information about previously undefined E6AP substrates is expected soon. While proteasome inhibitors are widely used in clinic [154-157], small molecules targeting E3 ligases are still in developmental or preclinical phases. Novel screening technologies will further build the avenue to therapeutic discoveries, such as activity-based probes, high-throughput crystallography, and sophisticated uses of mass spectrometry. In addition to inhibitors of E3 activities or protein-protein interactions, the promising techniques of targeted protein degradation, such as proteolysis targeting chimeras (PROTACs) and specific and nongenetic IAP-dependent protein erasers (SNIPER) [158-160], will widen the strategies to target the ubiquitination system in human diseases.

Funding: This research was funded by National Institute of General Medical Sciences: R01-GM104498; Chicago Biomedical Consortium: Catalyst Award C-026; the Department of Pharmacology at Northwestern University.

Acknowledgments: We thank Jun Yin, Yiyang Wang, Xianpeng Liu and Peter Penzes for helpful discussions.

Conflicts of Interest: The authors declare no conflict of interest.

\section{References}

1. Hershko, A.; Ciechanover, A. The ubiquitin system. Annu. Rev. Biochem. 1998, 67, 425-479. [CrossRef]

2. Tu, Y.; Chen, C.; Pan, J.; Xu, J.; Zhou, Z.G.; Wang, C.Y. The Ubiquitin Proteasome Pathway (UPP) in the regulation of cell cycle control and DNA damage repair and its implication in tumorigenesis. Int. J. Clin. Exp. Pathol. 2012, 5, 726-738. [PubMed] 
3. Zheng, N.; Shabek, N. Ubiquitin Ligases: Structure, Function, and Regulation. Annu. Rev. Biochem. 2017, 86, 129-157. [CrossRef] [PubMed]

4. Nawaz, Z.; Lonard, D.M.; Smith, C.L.; Lev-Lehman, E.; Tsai, S.Y.; Tsai, M.J.; O’Malley, B.W. The Angelman syndrome-associated protein, E6-AP, is a coactivator for the nuclear hormone receptor superfamily. Mol. Cell Biol. 1999, 19, 1182-1189. [CrossRef] [PubMed]

5. Huibregtse, J.M.; Scheffner, M.; Beaudenon, S.; Howley, P.M. A family of proteins structurally and functionally related to the E6-AP ubiquitin-protein ligase. Proc. Natl. Acad. Sci. USA 1995, 92, 2563. [CrossRef] [PubMed]

6. Huang, L.; Kinnucan, E.; Wang, G.; Beaudenon, S.; Howley, P.M.; Huibregtse, J.M.; Pavletich, N.P. Structure of an E6AP-UbcH7 complex: Insights into ubiquitination by the E2-E3 enzyme cascade. Science 1999, 286, 1321-1326. [CrossRef] [PubMed]

7. Rotin, D.; Kumar, S. Physiological functions of the HECT family of ubiquitin ligases. Nat. Rev. Mol. Cell Biol. 2009, 10, 398-409. [CrossRef]

8. Lemak, A.; Yee, A.; Bezsonova, I.; Dhe-Paganon, S.; Arrowsmith, C.H. Zn-binding AZUL domain of human ubiquitin protein ligase Ube3A. J. Biomol. NMR 2011, 51, 185-190. [CrossRef]

9. Cooper, E.M.; Hudson, A.W.; Amos, J.; Wagstaff, J.; Howley, P.M. Biochemical analysis of Angelman syndrome-associated mutations in the E3 ubiquitin ligase E6-associated protein. J. Biol. Chem. 2004, 279, 41208-41217. [CrossRef]

10. Sadikovic, B.; Fernandes, P.; Zhang, V.W.; Ward, P.A.; Miloslavskaya, I.; Rhead, W.; Rosenbaum, R.; Gin, R.; Roa, B.; Fang, P. Mutation Update for UBE3A variants in Angelman syndrome. Hum. Mutat. 2014, 35, 1407-1417. [CrossRef]

11. Bai, J.L.; Qu, Y.J.; Zou, L.P.; Yang, X.Y.; Liu, L.J.; Song, F. A novel missense mutation of the ubiquitin protein ligase E3A gene in a patient with Angelman syndrome. Chin. Med. J. 2011, 124, 84-88. [PubMed]

12. Khan, O.Y.; Fu, G.; Ismail, A.; Srinivasan, S.; Cao, X.; Tu, Y.; Lu, S.; Nawaz, Z. Multifunction steroid receptor coactivator, E6-associated protein, is involved in development of the prostate gland. Mol. Endocrinol. 2006, 20, 544-559. [CrossRef] [PubMed]

13. Ramamoorthy, S.; Nawaz, Z. E6-associated protein (E6-AP) is a dual function coactivator of steroid hormone receptors. Nucl. Recept. Signal. 2008, 6, nrs.06006. [CrossRef] [PubMed]

14. Heery, D.M.; Kalkhoven, E.; Hoare, S.; Parker, M.G. A signature motif in transcriptional co-activators mediates binding to nuclear receptors. Nature 1997, 387, 733-736. [CrossRef]

15. Hatakeyama, S.; Jensen, J.P.; Weissman, A.M. Subcellular localization and ubiquitin-conjugating enzyme (E2) interactions of mammalian HECT family ubiquitin protein ligases. J. Biol. Chem. 1997, 272, 15085-15092. [CrossRef] [PubMed]

16. Harlalka, G.V.; Baple, E.L.; Cross, H.; Kühnle, S.; Cubillos-Rojas, M.; Matentzoglu, K.; Patton, M.A.; Wagner, K.; Coblentz, R.; Ford, D.L.; et al. Mutation of HERC2 causes developmental delay with Angelman-like features. J. Med Genet. 2013, 50, 65-73. [CrossRef]

17. Kuhnle, S.; Kogel, U.; Glockzin, S.; Marquardt, A.; Ciechanover, A.; Matentzoglu, K.; Scheffner, M. Physical and functional interaction of the HECT ubiquitin-protein ligases E6AP and HERC2. J. Biol. Chem. 2011, 286, 19410-19416. [CrossRef]

18. Yi, J.J.; Berrios, J.; Newbern, J.M.; Snider, W.D.; Philpot, B.D.; Hahn, K.M.; Zylka, M.J. An Autism-Linked Mutation Disables Phosphorylation Control of UBE3A. Cell 2015, 162, 795-807. [CrossRef]

19. Scheffner, M.; Werness, B.A.; Huibregtse, J.M.; Levine, A.J.; Howley, P.M. The E6 oncoprotein encoded by human papillomavirus types 16 and 18 promotes the degradation of p53. Cell 1990, 63, 1129-1136. [CrossRef]

20. Wolyniec, K.; Shortt, J.; de Stanchina, E.; Levav-Cohen, Y.; Alsheich-Bartok, O.; Louria-Hayon, I.; Corneille, V.; Kumar, B.; Woods, S.J.; Opat, S.; et al. E6AP ubiquitin ligase regulates PML-induced senescence in Myc-driven lymphomagenesis. Blood 2012, 120, 822-832. [CrossRef]

21. Cheville, J.C.; Lloyd, R.V.; Sebo, T.J.; Cheng, L.; Erickson, L.; Bostwick, D.G.; Lohse, C.M.; Wollan, P. Expression of p27kip1 in prostatic adenocarcinoma. Mod. Pathol. 1998, 11, 324-328. [PubMed]

22. Gamell, C.; Gulati, T.; Levav-Cohen, Y.; Young, R.J.; Do, H.; Pilling, P.; Takano, E.; Watkins, N.; Fox, S.B.; Russell, P.; et al. Reduced abundance of the E3 ubiquitin ligase E6AP contributes to decreased expression of the INK4/ARF locus in non-small cell lung cancer. Sci. Signal 2017, 10. [CrossRef]

23. Gao, X.; Mohsin, S.K.; Gatalica, Z.; Fu, G.; Sharma, P.; Nawaz, Z. Decreased expression of e6-associated protein in breast and prostate carcinomas. Endocrinology 2005, 146, 1707-1712. [CrossRef] [PubMed]

24. Bandilovska, I.; Keam, S.P.; Gamell, C.; Machicado, C.; Haupt, S.; Haupt, Y. E6AP goes viral: The role of E6AP in viral- and non-viral-related cancers. Carcinogenesis 2019, 40, 707-714. [CrossRef] [PubMed] 
25. Scheffner, M.; Huibregtse, J.M.; Vierstra, R.D.; Howley, P.M. The HPV-16 E6 and E6-AP complex functions as a ubiquitin-protein ligase in the ubiquitination of p53. Cell 1993, 75, 495-505. [CrossRef]

26. Huibregtse, J.M.; Scheffner, M.; Howley, P.M. Localization of the E6-AP regions that direct human papillomavirus E6 binding, association with p53, and ubiquitination of associated proteins. Mol. Cell Biol. 1993, 13, 4918-4927. [CrossRef]

27. Scheffner, M.; Munger, K.; Huibregtse, J.M.; Howley, P.M. Targeted degradation of the retinoblastoma protein by human papillomavirus E7-E6 fusion proteins. EMBO J. 1992, 11, 2425-2431. [CrossRef]

28. de Oliveria Andrade, L.J.; D'Oliveira, A.; Melo, R.C.; De Souza, E.C.; Costa Silva, C.A.; Parana, R. Association between hepatitis $C$ and hepatocellular carcinoma. J. Glob. Infect Dis. 2009, 1, 33-37. [CrossRef]

29. Munakata, T.; Liang, Y.; Kim, S.; McGivern, D.R.; Huibregtse, J.; Nomoto, A.; Lemon, S.M. Hepatitis C virus induces E6AP-dependent degradation of the retinoblastoma protein. PLoS Pathog. 2007, 3, 1335-1347. [CrossRef]

30. Shirakura, M.; Murakami, K.; Ichimura, T.; Suzuki, R.; Shimoji, T.; Fukuda, K.; Abe, K.; Sato, S.; Fukasawa, M.; Yamakawa, Y.; et al. E6AP ubiquitin ligase mediates ubiquitylation and degradation of hepatitis $\mathrm{C}$ virus core protein. J. Virol. 2007, 81, 1174-1185. [CrossRef]

31. Kwak, J.; Shim, J.H.; Tiwari, I.; Jang, K.L. Hepatitis C virus core protein inhibits E6AP expression via DNA methylation to escape from ubiquitin-dependent proteasomal degradation. Cancer Lett. 2016, 380, 59-68. [CrossRef] [PubMed]

32. Louria-Hayon, I.; Alsheich-Bartok, O.; Levav-Cohen, Y.; Silberman, I.; Berger, M.; Grossman, T.; Matentzoglu, K.; Jiang, Y.H.; Muller, S.; Scheffner, M.; et al. E6AP promotes the degradation of the PML tumor suppressor. Cell Death Differ. 2009, 16, 1156-1166. [CrossRef] [PubMed]

33. de The, H.; Chomienne, C.; Lanotte, M.; Degos, L.; Dejean, A. The t(15;17) translocation of acute promyelocytic leukaemia fuses the retinoic acid receptor alpha gene to a novel transcribed locus. Nature 1990, 347, 558-561. [CrossRef] [PubMed]

34. Kakizuka, A.; Miller, W.H., Jr.; Umesono, K.; Warrell, R.P., Jr.; Frankel, S.R.; Murty, V.V.; Dmitrovsky, E.; Evans, R.M. Chromosomal translocation $\mathrm{t}(15 ; 17)$ in human acute promyelocytic leukemia fuses RAR alpha with a novel putative transcription factor, PML. Cell 1991, 66, 663-674. [CrossRef]

35. Gurrieri, C.; Capodieci, P.; Bernardi, R.; Scaglioni, P.P.; Nafa, K.; Rush, L.J.; Verbel, D.A.; Cordon-Cardo, C.; Pandolfi, P.P. Loss of the tumor suppressor PML in human cancers of multiple histologic origins. J. Natl. Cancer Inst. 2004, 96, 269-279. [CrossRef]

36. Sahin, U.; Ferhi, O.; Jeanne, M.; Benhenda, S.; Berthier, C.; Jollivet, F.; Niwa-Kawakita, M.; Faklaris, O.; Setterblad, N.; de Thé, H.; et al. Oxidative stress-induced assembly of PML nuclear bodies controls sumoylation of partner proteins. J. Cell Biol. 2014, 204, 931-945. [CrossRef]

37. Bernardi, R.; Guernah, I.; Jin, D.; Grisendi, S.; Alimonti, A.; Teruya-Feldstein, J.; Cordon-Cardo, C.; Simon, M.C.; Rafii, S.; Pandolfi, P.P. PML inhibits HIF-1alpha translation and neoangiogenesis through repression of mTOR. Nature 2006, 442, 779-785. [CrossRef]

38. de Stanchina, E.; Querido, E.; Narita, M.; Davuluri, R.V.; Pandolfi, P.P.; Ferbeyre, G.; Lowe, S.W. PML is a direct p53 target that modulates p53 effector functions. Mol. Cell 2004, 13, 523-535. [CrossRef]

39. Dellaire, G.; Bazett-Jones, D.P. PML nuclear bodies: Dynamic sensors of DNA damage and cellular stress. Bioessays 2004, 26, 963-977. [CrossRef]

40. Dellaire, G.; Ching, R.W.; Ahmed, K.; Jalali, F.; Tse, K.C.; Bristow, R.G.; Bazett-Jones, D.P. Promyelocytic leukemia nuclear bodies behave as DNA damage sensors whose response to DNA double-strand breaks is regulated by NBS1 and the kinases ATM, Chk2, and ATR. J. Cell Biol. 2006, 175, 55-66. [CrossRef]

41. Giorgi, C.; Ito, K.; Lin, H.K.; Santangelo, C.; Wieckowski, M.R.; Lebiedzinska, M.; Bononi, A.; Bonora, M.; Duszynski, J.; Bernardi, R.; et al. PML regulates apoptosis at endoplasmic reticulum by modulating calcium release. Science 2010, 330, 1247-1251. [CrossRef] [PubMed]

42. Gresko, E.; Ritterhoff, S.; Sevilla-Perez, J.; Roscic, A.; Frobius, K.; Kotevic, I.; Vichalkovski, A.; Hess, D.; Hemmings, B.A.; Schmitz, M.L. PML tumor suppressor is regulated by HIPK2-mediated phosphorylation in response to DNA damage. Oncogene 2009, 28, 698-708. [CrossRef] [PubMed]

43. Guo, A.; Salomoni, P.; Luo, J.; Shih, A.; Zhong, S.; Gu, W.; Pandolfi, P.P. The function of PML in p53-dependent apoptosis. Nat. Cell Biol. 2000, 2, 730-736. [CrossRef] [PubMed]

44. Hsu, K.S.; Zhao, X.; Cheng, X.; Guan, D.; Mahabeleshwar, G.H.; Liu, Y.; Borden, E.; Jain, M.K.; Kao, H.Y. Dual regulation of Stat 1 and Stat 3 by the tumor suppressor protein PML contributes to interferon alpha-mediated inhibition of angiogenesis. J. Biol. Chem. 2017, 292, 10048-10060. [CrossRef] [PubMed] 
45. Lin, H.K.; Bergmann, S.; Pandolfi, P.P. Cytoplasmic PML function in TGF-beta signalling. Nature 2004, 431, 205-211. [CrossRef]

46. Oh, W.; Ghim, J.; Lee, E.-W.; Yang, M.-R.; Kim, E.T.; Ahn, J.-H.; Song, J. PML-IV functions as a negative regulator of telomerase by interacting with TERT. J. Cell Sci. 2009, 122, 2613-2622. [CrossRef]

47. Pearson, M.; Carbone, R.; Sebastiani, C.; Cioce, M.; Fagioli, M.; Saito, S.; Higashimoto, Y.; Appella, E.; Minucci, S.; Pandolfi, P.P.; et al. PML regulates p53 acetylation and premature senescence induced by oncogenic Ras. Nature 2000, 406, 207-210. [CrossRef]

48. Reineke, E.L.; Lam, M.; Liu, Q.; Liu, Y.; Stanya, K.J.; Chang, K.S.; Means, A.R.; Kao, H.Y. Degradation of the tumor suppressor PML by Pin1 contributes to the cancer phenotype of breast cancer MDA-MB-231 cells. Mol. Cell Biol. 2008, 28, 997-1006. [CrossRef]

49. Reineke, E.L.; Liu, Y.; Kao, H.-Y. Promyelocytic leukemia protein controls cell migration in response to hydrogen peroxide and insulin-like growth factor-1. J. Biol. Chem. 2010, 285, 9485-9492. [CrossRef]

50. Vernier, M.; Ferbeyre, G. Complete senescence: RB and PML share the task. Cell Cycle 2014, 13, 696. [CrossRef]

51. Srinivasan, S.; Nawaz, Z. E3 ubiquitin protein ligase, E6-associated protein (E6-AP) regulates PI3K-Akt signaling and prostate cell growth. Biochim. Biophys. Acta 2011, 1809, 119-127. [CrossRef] [PubMed]

52. Paul, P.J.; Raghu, D.; Chan, A.L.; Gulati, T.; Lambeth, L.; Takano, E.; Herold, M.J.; Hagekyriakou, J.; Vessella, R.L.; Fedele, C.; et al. Restoration of tumor suppression in prostate cancer by targeting the E3 ligase E6AP. Oncogene 2016, 35, 6235-6245. [CrossRef] [PubMed]

53. Gulati, T.; Huang, C.; Caramia, F.; Raghu, D.; Paul, P.J.; Goode, R.J.A.; Keam, S.P.; Williams, S.G.; Haupt, S.; Kleifeld, O.; et al. Proteotranscriptomic Measurements of E6-Associated Protein (E6AP) Targets in DU145 Prostate Cancer Cells. Mol. Cell Proteom. 2018, 17, 1170-1183. [CrossRef] [PubMed]

54. Ramamoorthy, S.; Tufail, R.; Hokayem, J.E.; Jorda, M.; Zhao, W.; Reis, Z.; Nawaz, Z. Overexpression of ligase defective E6-associated protein, E6-AP, results in mammary tumorigenesis. Breast Cancer Res. Treat. 2012, 132, 97-108. [CrossRef] [PubMed]

55. Li, L.; Li, Z.; Howley, P.M.; Sacks, D.B. E6AP and calmodulin reciprocally regulate estrogen receptor stability. J. Biol. Chem. 2006, 281, 1978-1985. [CrossRef]

56. Anzick, S.L.; Kononen, J.; Walker, R.L.; Azorsa, D.O.; Tanner, M.M.; Guan, X.Y.; Sauter, G.; Kallioniemi, O.P.; Trent, J.M.; Meltzer, P.S. AIB1, a steroid receptor coactivator amplified in breast and ovarian cancer. Science 1997, 277, 965-968. [CrossRef]

57. Torres-Arzayus, M.I.; Font de Mora, J.; Yuan, J.; Vazquez, F.; Bronson, R.; Rue, M.; Sellers, W.R.; Brown, M. High tumor incidence and activation of the PI3K/AKT pathway in transgenic mice define AIB1 as an oncogene. Cancer Cell 2004, 6, 263-274. [CrossRef]

58. Tilli, M.T.; Reiter, R.; Oh, A.S.; Henke, R.T.; McDonnell, K.; Gallicano, G.I.; Furth, P.A.; Riegel, A.T. Overexpression of an N-terminally truncated isoform of the nuclear receptor coactivator amplified in breast cancer 1 leads to altered proliferation of mammary epithelial cells in transgenic mice. Mol. Endocrinol 2005, 19, 644-656. [CrossRef]

59. Alkner, S.; Jensen, M.B.; Rasmussen, B.B.; Bendahl, P.O.; Fernö, M.; Rydén, L.; Mouridsen, H.; Danish Breast Cancer Cooperative, G. Prognostic and predictive importance of the estrogen receptor coactivator AIB1 in a randomized trial comparing adjuvant letrozole and tamoxifen therapy in postmenopausal breast cancer: The Danish cohort of BIG 1-98. Breast Cancer Res. Treat. 2017, 166, 481-490. [CrossRef]

60. Lee, K.; Lee, A.; Song, B.J.; Kang, C.S. Expression of AIB1 protein as a prognostic factor in breast cancer. World J. Surg. Oncol. 2011, 9, 139. [CrossRef]

61. Ory, V.; Tassi, E.; Cavalli, L.R.; Sharif, G.M.; Saenz, F.; Baker, T.; Schmidt, M.O.; Mueller, S.C.; Furth, P.A.; Wellstein, A.; et al. The nuclear coactivator amplified in breast cancer 1 maintains tumor-initiating cells during development of ductal carcinoma in situ. Oncogene 2014, 33, 3033-3042. [CrossRef] [PubMed]

62. Mani, A.; Oh, A.S.; Bowden, E.T.; Lahusen, T.; Lorick, K.L.; Weissman, A.M.; Schlegel, R.; Wellstein, A.; Riegel, A.T. E6AP mediates regulated proteasomal degradation of the nuclear receptor coactivator amplified in breast cancer 1 in immortalized cells. Cancer Res. 2006, 66, 8680-8686. [CrossRef] [PubMed]

63. Mishra, M.; Sharma, A.; Thacker, G.; Trivedi, A.K. Nano-LC based proteomic approach identifies that E6AP interacts with ENO1 and targets it for degradation in breast cancer cells. IUBMB Life 2019, 71, 1896-1905. [CrossRef] [PubMed]

64. Tu, S.H.; Chang, C.C.; Chen, C.S.; Tam, K.W.; Wang, Y.J.; Lee, C.H.; Lin, H.W.; Cheng, T.C.; Huang, C.S.; $\mathrm{Chu}$, J.S.; et al. Increased expression of enolase alpha in human breast cancer confers tamoxifen resistance in human breast cancer cells. Breast Cancer Res. Treat. 2010, 121, 539-553. [CrossRef] [PubMed] 
65. Pancholi, V. Multifunctional alpha-enolase: Its role in diseases. Cell Mol. Life Sci. 2001, 58, 902-920. [CrossRef] [PubMed]

66. Hsiao, K.C.; Shih, N.Y.; Fang, H.L.; Huang, T.S.; Kuo, C.C.; Chu, P.Y.; Hung, Y.M.; Chou, S.W.; Yang, Y.Y.; Chang, G.C.; et al. Surface alpha-enolase promotes extracellular matrix degradation and tumor metastasis and represents a new therapeutic target. PLoS ONE 2013, 8, e69354. [CrossRef]

67. Raghu, D.; Paul, P.J.; Gulati, T.; Deb, S.; Khoo, C.; Russo, A.; Gallo, E.; Blandino, G.; Chan, A.-L.; Takano, E.; et al. E6AP promotes prostate cancer by reducing p27 expression. Oncotarget 2017, 8, 42939-42948. [CrossRef]

68. Aloni-Grinstein, R.; Charni-Natan, M.; Solomon, H.; Rotter, V. p53 and the Viral Connection: Back into the Future (double dagger). Cancers (Basel) 2018, 10, 178. [CrossRef]

69. Kumar, S.; Talis, A.L.; Howley, P.M. Identification of HHR23A as a substrate for E6-associated protein-mediated ubiquitination. J. Biol. Chem. 1999, 274, 18785-18792. [CrossRef]

70. Rougeulle, C.; Glatt, H.; Lalande, M. The Angelman syndrome candidate gene, UBE3AIE6-AP, is imprinted in brain. Nat. Genet. 1997, 17, 14-15. [CrossRef]

71. Vu, T.H.; Hoffman, A.R. Imprinting of the Angelman syndrome gene, UBE3A, is restricted to brain. Nat. Genet 1997, 17, 12-13. [CrossRef] [PubMed]

72. Chamberlain, S.J.; Brannan, C.I. The Prader-Willi syndrome imprinting center activates the paternally expressed murine Ube3a antisense transcript but represses paternal Ube3a. Genomics 2001, 73, 316-322. [CrossRef] [PubMed]

73. Borgatti, R.; Piccinelli, P.; Passoni, D.; Dalpra, L.; Miozzo, M.; Micheli, R.; Gagliardi, C.; Balottin, U. Relationship between clinical and genetic features in "inverted duplicated chromosome 15" patients. Pediatr. Neurol. 2001, 24, 111-116. [CrossRef]

74. Dindot, S.V.; Antalffy, B.A.; Bhattacharjee, M.B.; Beaudet, A.L. The Angelman syndrome ubiquitin ligase localizes to the synapse and nucleus, and maternal deficiency results in abnormal dendritic spine morphology. Hum. Mol. Genet. 2008, 17, 111-118. [CrossRef]

75. Miao, S.; Chen, R.; Ye, J.; Tan, G.H.; Li, S.; Zhang, J.; Jiang, Y.H.; Xiong, Z.Q. The Angelman syndrome protein Ube3a is required for polarized dendrite morphogenesis in pyramidal neurons. J. Neurosci. 2013, 33, 327-333. [CrossRef]

76. Khatri, N.; Gilbert, J.P.; Huo, Y.; Sharaflari, R.; Nee, M.; Qiao, H.; Man, H.Y. The Autism Protein Ube3A/E6AP Remodels Neuronal Dendritic Arborization via Caspase-Dependent Microtubule Destabilization. J. Neurosci. 2018, 38, 363-378. [CrossRef]

77. Lisman, J.; Yasuda, R.; Raghavachari, S. Mechanisms of CaMKII action in long-term potentiation. Nat. Rev. Neurosci. 2012, 13,169-182. [CrossRef]

78. Yashiro, K.; Riday, T.T.; Condon, K.H.; Roberts, A.C.; Bernardo, D.R.; Prakash, R.; Weinberg, R.J.; Ehlers, M.D.; Philpot, B.D. Ube3a is required for experience-dependent maturation of the neocortex. Nat. Neurosci. 2009, 12,777-783. [CrossRef]

79. Sato, M.; Stryker, M.P. Genomic imprinting of experience-dependent cortical plasticity by the ubiquitin ligase gene Ube3a. Proc. Natl. Acad. Sci. USA 2010, 107, 5611-5616. [CrossRef]

80. Greer, P.L.; Hanayama, R.; Bloodgood, B.L.; Mardinly, A.R.; Lipton, D.M.; Flavell, S.W.; Kim, T.K.; Griffith, E.C.; Waldon, Z.; Maehr, R.; et al. The Angelman Syndrome protein Ube3A regulates synapse development by ubiquitinating arc. Cell 2010, 140, 704-716. [CrossRef]

81. Kühnle, S.; Mothes, B.; Matentzoglu, K.; Scheffner, M. Role of the ubiquitin ligase E6AP/UBE3A in controlling levels of the synaptic protein Arc. Proc. Natl. Acad. Sci. USA 2013, 110, 8888-8893. [CrossRef] [PubMed]

82. Sun, J.; Zhu, G.; Liu, Y.; Standley, S.; Ji, A.; Tunuguntla, R.; Wang, Y.; Claus, C.; Luo, Y.; Baudry, M.; et al. UBE3A Regulates Synaptic Plasticity and Learning and Memory by Controlling SK2 Channel Endocytosis. Cell Rep. 2015, 12, 449-461. [CrossRef] [PubMed]

83. Margolis, S.S.; Salogiannis, J.; Lipton, D.M.; Mandel-Brehm, C.; Wills, Z.P.; Mardinly, A.R.; Hu, L.; Greer, P.L.; Bikoff, J.B.; Ho, H.Y.; et al. EphB-mediated degradation of the RhoA GEF Ephexin5 relieves a developmental brake on excitatory synapse formation. Cell 2010, 143, 442-455. [CrossRef] [PubMed]

84. Fiumara, A.; Pittalà, A.; Cocuzza, M.; Sorge, G. Epilepsy in patients with Angelman syndrome. Ital. J. Pediatr. 2010, 36, 31. [CrossRef]

85. Wallace, M.L.; Burette, A.C.; Weinberg, R.J.; Philpot, B.D. Maternal loss of Ube3a produces an excitatory/inhibitory imbalance through neuron type-specific synaptic defects. Neuron 2012, 74, 793-800. [CrossRef] 
86. Nelson, S.B.; Valakh, V. Excitatory/Inhibitory Balance and Circuit Homeostasis in Autism Spectrum Disorders. Neuron 2015, 87, 684-698. [CrossRef]

87. Egawa, K.; Kitagawa, K.; Inoue, K.; Takayama, M.; Takayama, C.; Saitoh, S.; Kishino, T.; Kitagawa, M.; Fukuda, A. Decreased tonic inhibition in cerebellar granule cells causes motor dysfunction in a mouse model of Angelman syndrome. Sci. Transl. Med. 2012, 4, 163ra157. [CrossRef]

88. Gu, B.; Carstens, K.E.; Judson, M.C.; Dalton, K.A.; Rougie, M.; Clark, E.P.; Dudek, S.M.; Philpot, B.D. Ube3a reinstatement mitigates epileptogenesis in Angelman syndrome model mice. J. Clin. Investig. 2019, 129, 163-168. [CrossRef]

89. Pelc, K.; Cheron, G.; Boyd, S.G.; Dan, B. Are there distinctive sleep problems in Angelman syndrome? Sleep Med. 2008, 9, 434-441. [CrossRef]

90. Gossan, N.C.; Zhang, F.; Guo, B.; Jin, D.; Yoshitane, H.; Yao, A.; Glossop, N.; Zhang, Y.Q.; Fukada, Y.; Meng, Q.J. The E3 ubiquitin ligase UBE3A is an integral component of the molecular circadian clock through regulating the BMAL1 transcription factor. Nucleic Acids Res. 2014, 42, 5765-5775. [CrossRef]

91. Shi, S.Q.; Bichell, T.J.; Ihrie, R.A.; Johnson, C.H. Ube3a imprinting impairs circadian robustness in Angelman syndrome models. Curr. Biol. 2015, 25, 537-545. [CrossRef] [PubMed]

92. Yi, J.J.; Paranjape, S.R.; Walker, M.P.; Choudhury, R.; Wolter, J.M.; Fragola, G.; Emanuele, M.J.; Major, M.B.; Zylka, M.J. The autism-linked UBE3A T485A mutant E3 ubiquitin ligase activates the Wnt/ $\beta$-catenin pathway by inhibiting the proteasome. J. Biol. Chem. 2017, 292, 12503-12515. [CrossRef] [PubMed]

93. De Rubeis, S.; He, X.; Goldberg, A.P.; Poultney, C.S.; Samocha, K.; Cicek, A.E.; Kou, Y.; Liu, L.; Fromer, M.; Walker, S.; et al. Synaptic, transcriptional and chromatin genes disrupted in autism. Nature 2014, 515, $209-215$. [CrossRef]

94. Krumm, N.; O’Roak, B.J.; Shendure, J.; Eichler, E.E. A de novo convergence of autism genetics and molecular neuroscience. Trends Neurosci. 2014, 37, 95-105. [CrossRef] [PubMed]

95. Zheng, L.; Ding, H.; Lu, Z.; Li, Y.; Pan, Y.; Ning, T.; Ke, Y. E3 ubiquitin ligase E6AP-mediated TSC2 turnover in the presence and absence of HPV16 E6. Genes. Cells 2008, 13, 285-294. [CrossRef]

96. Sun, J.; Liu, Y.; Moreno, S.; Baudry, M.; Bi, X. Imbalanced mechanistic target of rapamycin C1 and C2 activity in the cerebellum of Angelman syndrome mice impairs motor function. J. Neurosci. 2015, 35, 4706-4718. [CrossRef]

97. Zaaroor-Regev, D.; de Bie, P.; Scheffner, M.; Noy, T.; Shemer, R.; Heled, M.; Stein, I.; Pikarsky, E.; Ciechanover, A. Regulation of the polycomb protein Ring1B by self-ubiquitination or by E6-AP may have implications to the pathogenesis of Angelman syndrome. Proc. Natl. Acad. Sci. USA 2010, 107, 6788-6793. [CrossRef]

98. Picard, N.; Charbonneau, C.; Sanchez, M.; Licznar, A.; Busson, M.; Lazennec, G.; Tremblay, A. Phosphorylation of activation function-1 regulates proteasome-dependent nuclear mobility and E6-associated protein ubiquitin ligase recruitment to the estrogen receptor beta. Mol. Endocrinol. 2008, 22, 317-330. [CrossRef]

99. Tian, Z.; Fan, J.; Zhao, Y.; Bi, S.; Si, L.; Liu, Q. Estrogen receptor beta treats Alzheimer's disease. Neural. Regen Res. 2013, 8, 420-426. [CrossRef]

100. Long, J.; He, P.; Shen, Y.; Li, R. New evidence of mitochondria dysfunction in the female Alzheimer's disease brain: Deficiency of estrogen receptor-beta. J. Alzheimers Dis. 2012, 30, 545-558. [CrossRef]

101. Sohrabji, F.; Miranda, R.C.; Toran-Allerand, C.D. Identification of a putative estrogen response element in the gene encoding brain-derived neurotrophic factor. Proc. Natl. Acad. Sci. USA 1995, 92, 11110-11114. [CrossRef] [PubMed]

102. Aguirre, C.; Jayaraman, A.; Pike, C.; Baudry, M. Progesterone inhibits estrogen-mediated neuroprotection against excitotoxicity by down-regulating estrogen receptor-beta. J. Neurochem. 2010, 115, 1277-1287. [CrossRef] [PubMed]

103. Jacobson, A.D.; MacFadden, A.; Wu, Z.; Peng, J.; Liu, C.W. Autoregulation of the 26 S proteasome by in situ ubiquitination. Mol. Biol. Cell 2014, 25, 1824-1835. [CrossRef] [PubMed]

104. Avagliano Trezza, R.; Sonzogni, M.; Bossuyt, S.N.V.; Zampeta, F.I.; Punt, A.M.; van den Berg, M.; Rotaru, D.C.; Koene, L.M.C.; Munshi, S.T.; Stedehouder, J.; et al. Loss of nuclear UBE3A causes electrophysiological and behavioral deficits in mice and is associated with Angelman syndrome. Nat. Neurosci. 2019, 22, 1235-1247. [CrossRef]

105. Xu, X.; Li, C.; Gao, X.; Xia, K.; Guo, H.; Li, Y.; Hao, Z.; Zhang, L.; Gao, D.; Xu, C.; et al. Excessive UBE3A dosage impairs retinoic acid signaling and synaptic plasticity in autism spectrum disorders. Cell Res. 2018, 28, 48-68. [CrossRef] 
106. Wang, J.; Lou, S.S.; Wang, T.; Wu, R.J.; Li, G.; Zhao, M.; Lu, B.; Li, Y.Y.; Zhang, J.; Cheng, X.; et al. UBE3A-mediated PTPA ubiquitination and degradation regulate PP2A activity and dendritic spine morphology. Proc. Natl. Acad. Sci. USA 2019, 116, 12500-12505. [CrossRef]

107. Mabb, A.M.; Ehlers, M.D. Arc ubiquitination in synaptic plasticity. Semin Cell Dev. Biol. 2018, 77, 10-16. [CrossRef]

108. Mandel-Brehm, C.; Salogiannis, J.; Dhamne, S.C.; Rotenberg, A.; Greenberg, M.E. Seizure-like activity in a juvenile Angelman syndrome mouse model is attenuated by reducing Arc expression. Proc. Natl. Acad. Sci. USA 2015, 112, 5129-5134. [CrossRef]

109. Day, M.; Sung, A.; Logue, S.; Bowlby, M.; Arias, R. Beta estrogen receptor knockout (BERKO) mice present attenuated hippocampal CA1 long-term potentiation and related memory deficits in contextual fear conditioning. Behav. Brain Res. 2005, 164, 128-131. [CrossRef]

110. Rissman, E.F.; Heck, A.L.; Leonard, J.E.; Shupnik, M.A.; Gustafsson, J.A. Disruption of estrogen receptor beta gene impairs spatial learning in female mice. Proc. Natl. Acad. Sci. USA 2002, 99, 3996-4001. [CrossRef]

111. Deng, B.; Ye, N.; Luo, G.; Chen, X.; Wang, Y. Proteomics analysis of stage-specific proteins expressed in human squamous cell lung carcinoma tissues. Cancer Biomark 2005, 1, 279-286. [CrossRef]

112. Karihtala, P.; Mantyniemi, A.; Kang, S.W.; Kinnula, V.L.; Soini, Y. Peroxiredoxins in breast carcinoma. Clin. Cancer Res. 2003, 9, 3418-3424. [PubMed]

113. Nasu, J.; Murakami, K.; Miyagawa, S.; Yamashita, R.; Ichimura, T.; Wakita, T.; Hotta, H.; Miyamura, T.; Suzuki, T.; Satoh, T.; et al. E6AP ubiquitin ligase mediates ubiquitin-dependent degradation of peroxiredoxin 1. J. Cell Biochem. 2010, 111, 676-685. [CrossRef] [PubMed]

114. Ren, P.; Ye, H.; Dai, L.; Liu, M.; Liu, X.; Chai, Y.; Shao, Q.; Li, Y.; Lei, N.; Peng, B.; et al. Peroxiredoxin 1 is a tumor-associated antigen in esophageal squamous cell carcinoma. Oncol. Rep. 2013, 30, 2297-2303. [CrossRef] [PubMed]

115. Riddell, J.R.; Bshara, W.; Moser, M.T.; Spernyak, J.A.; Foster, B.A.; Gollnick, S.O. Peroxiredoxin 1 controls prostate cancer growth through Toll-like receptor 4-dependent regulation of tumor vasculature. Cancer Res. 2011, 71, 1637-1646. [CrossRef]

116. Lizarraga, S.B.; Morrow, E.M. Uncovering a Role for SK2 in Angelman Syndrome. Cell Rep. 2015, 12, 359-360. [CrossRef]

117. Huang, X.; Wu, Z.; Mei, Y.; Wu, M. XIAP inhibits autophagy via XIAP-Mdm2-p53 signalling. EMBO J. 2013, 32, 2204-2216. [CrossRef]

118. McManus, D.C.; Lefebvre, C.A.; Cherton-Horvat, G.; St-Jean, M.; Kandimalla, E.R.; Agrawal, S.; Morris, S.J.; Durkin, J.P.; LaCasse, E.C. Loss of XIAP protein expression by RNAi and antisense approaches sensitizes cancer cells to functionally diverse chemotherapeutics. Oncogene 2004, 23, 8105-8117. [CrossRef]

119. Mehrotra, S.; Languino, L.R.; Raskett, C.M.; Mercurio, A.M.; Dohi, T.; Altieri, D.C. IAP Regulation of Metastasis. Cancer Cell 2010, 17, 53-64. [CrossRef]

120. Sun, J.; Liu, Y.; Jia, Y.; Hao, X.; Lin, W.j.; Tran, J.; Lynch, G.; Baudry, M.; Bi, X. UBE3A-mediated p18/LAMTOR1 ubiquitination and degradation regulate mTORC1 activity and synaptic plasticity. eLife 2018, 7, e37993. [CrossRef]

121. Arkin, M.R.; Tang, Y.; Wells, J.A. Small-molecule inhibitors of protein-protein interactions: Progressing toward the reality. Chem. Biol. 2014, 21, 1102-1114. [CrossRef] [PubMed]

122. Cohen, P.; Tcherpakov, M. Will the ubiquitin system furnish as many drug targets as protein kinases? Cell 2010, 143, 686-693. [CrossRef] [PubMed]

123. Johansson, H.; Isabella Tsai, Y.C.; Fantom, K.; Chung, C.W.; Kumper, S.; Martino, L.; Thomas, D.A.; Eberl, H.C.; Muelbaier, M.; House, D.; et al. Fragment-Based Covalent Ligand Screening Enables Rapid Discovery of Inhibitors for the RBR E3 Ubiquitin Ligase HOIP. J. Am. Chem. Soc. 2019, 141, 2703-2712. [CrossRef]

124. De Cesare, V.; Johnson, C.; Barlow, V.; Hastie, J.; Knebel, A.; Trost, M. The MALDI-TOF E2/E3 Ligase Assay as Universal Tool for Drug Discovery in the Ubiquitin Pathway. Cell Chem. Biol. 2018, 25, 1117-1127.e4. [CrossRef] [PubMed]

125. Tian, M.; Zeng, T.; Liu, M.; Han, S.; Lin, H.; Lin, Q.; Li, L.; Jiang, T.; Li, G.; Lin, H.; et al. A cell-based high-throughput screening method based on a ubiquitin-reference technique for identifying modulators of E3 ligases. J. Biol. Chem. 2019, 294, 2880-2891. [CrossRef]

126. Testa, A.; Lucas, X.; Castro, G.V.; Chan, K.H.; Wright, J.E.; Runcie, A.C.; Gadd, M.S.; Harrison, W.T.A.; Ko, E.J.; Fletcher, D.; et al. 3-Fluoro-4-hydroxyprolines: Synthesis, Conformational Analysis, and Stereoselective Recognition by the VHL E3 Ubiquitin Ligase for Targeted Protein Degradation. J. Am. Chem. Soc. 2018, 140, 9299-9313. [CrossRef] 
127. Watt, J.E.; Hughes, G.R.; Walpole, S.; Monaco, S.; Stephenson, G.R.; Bulman Page, P.C.; Hemmings, A.M.; Angulo, J.; Chantry, A. Discovery of Small Molecule WWP2 Ubiquitin Ligase Inhibitors. Chemistry 2018, 24, 17677-17680. [CrossRef]

128. Ward, C.C.; Kleinman, J.I.; Brittain, S.M.; Lee, P.S.; Chung, C.Y.S.; Kim, K.; Petri, Y.; Thomas, J.R.; Tallarico, J.A.; McKenna, J.M.; et al. Covalent Ligand Screening Uncovers a RNF4 E3 Ligase Recruiter for Targeted Protein Degradation Applications. ACS Chem. Biol. 2019, 14, 2430-2440. [CrossRef]

129. Brenke, J.K.; Popowicz, G.M.; Schorpp, K.; Rothenaigner, I.; Roesner, M.; Meininger, I.; Kalinski, C.; Ringelstetter, L.; R'Kyek, O.; Jurjens, G.; et al. Targeting TRAF6 E3 ligase activity with a small-molecule inhibitor combats autoimmunity. J. Biol. Chem. 2018, 293, 13191-13203. [CrossRef]

130. Martinez-Zapien, D.; Ruiz, F.X.; Poirson, J.; Mitschler, A.; Ramirez, J.; Forster, A.; Cousido-Siah, A.; Masson, M.; Pol, S.V.; Podjarny, A.; et al. Structure of the E6/E6AP/p53 complex required for HPV-mediated degradation of p53. Nature 2016, 529, 541-545. [CrossRef]

131. Sailer, C.; Offensperger, F.; Julier, A.; Kammer, K.-M.; Walker-Gray, R.; Gold, M.G.; Scheffner, M.; Stengel, F. Structural dynamics of the E6AP/UBE3A-E6-p53 enzyme-substrate complex. Nat. Commun. 2018, 9, 4441. [CrossRef] [PubMed]

132. Celegato, M.; Messa, L.; Goracci, L.; Mercorelli, B.; Bertagnin, C.; Spyrakis, F.; Suarez, I.; Cousido-Siah, A.; Trave, G.; Banks, L.; et al. A novel small-molecule inhibitor of the human papillomavirus E6-p53 interaction that reactivates p53 function and blocks cancer cells growth. Cancer Lett. 2020, 470, 115-125. [CrossRef]

133. Zanier, K.; Charbonnier, S.; Sidi, A.O.M.h.O.; McEwen, A.G.; Ferrario, M.G.; Poussin-Courmontagne, P.; Cura, V.; Brimer, N.; Babah, K.O.; Ansari, T.; et al. Structural basis for hijacking of cellular LxxLL motifs by papillomavirus E6 oncoproteins. Science 2013, 339, 694-698. [CrossRef] [PubMed]

134. Cherry, J.J.; Rietz, A.; Malinkevich, A.; Liu, Y.; Xie, M.; Bartolowits, M.; Davisson, V.J.; Baleja, J.D.; Androphy, E.J. Structure based identification and characterization of flavonoids that disrupt human papillomavirus-16 E6 function. PLoS ONE 2013, 8, e84506. [CrossRef] [PubMed]

135. Ricci-López, J.; Vidal-Limon, A.; Zunñiga, M.; Jimènez, V.A.; Alderete, J.B.; Brizuela, C.A.; Aguila, S. Molecular modeling simulation studies reveal new potential inhibitors against HPV E6 protein. PLoS ONE 2019, 14, e0213028. [CrossRef]

136. Beerheide, W.; Bernard, H.U.; Tan, Y.J.; Ganesan, A.; Rice, W.G.; Ting, A.E. Potential drugs against cervical cancer: Zinc-Ejecting inhibitors of the human papillomavirus type 16 E6 oncoprotein. J. Natl. Cancer Inst. 1999, 91, 1211-1220. [CrossRef]

137. Dymalla, S.; Scheffner, M.; Weber, E.; Sehr, P.; Lohrey, C.; Hoppe-Seyler, F.; Hoppe-Seyler, K. A novel peptide motif binding to and blocking the intracellular activity of the human papillomavirus E6 oncoprotein. J. Mol. Med. 2009, 87, 321-331. [CrossRef]

138. Griffin, H.; Elston, R.; Jackson, D.; Ansell, K.; Coleman, M.; Winter, G.; Doorbar, J. Inhibition of Papillomavirus Protein Function in Cervical Cancer Cells by Intrabody Targeting. J. Mol. Biol. 2006, 355, 360-378. [CrossRef]

139. Lobato, M.N.; Rabbitts, T.H. Intracellular antibodies as specific reagents for functional ablation: Future therapeutic molecules. Curr. Mol. Med. 2004, 4, 519-528. [CrossRef]

140. Huang, H.S.; Allen, J.A.; Mabb, A.M.; King, I.F.; Miriyala, J.; Taylor-Blake, B.; Sciaky, N.; Dutton, J.W., Jr.; Lee, H.M.; Chen, X.; et al. Topoisomerase inhibitors unsilence the dormant allele of Ube3a in neurons. Nature 2011, 481, 185-189. [CrossRef]

141. King, I.F.; Yandava, C.N.; Mabb, A.M.; Hsiao, J.S.; Huang, H.S.; Pearson, B.L.; Calabrese, J.M.; Starmer, J.; Parker, J.S.; Magnuson, T.; et al. Topoisomerases facilitate transcription of long genes linked to autism. Nature 2013, 501, 58-62. [CrossRef] [PubMed]

142. Mabb, A.M.; Kullmann, P.H.; Twomey, M.A.; Miriyala, J.; Philpot, B.D.; Zylka, M.J. Topoisomerase 1 inhibition reversibly impairs synaptic function. Proc. Natl. Acad. Sci. USA 2014,111, 17290-17295. [CrossRef] [PubMed]

143. Meng, L.; Ward, A.J.; Chun, S.; Bennett, C.F.; Beaudet, A.L.; Rigo, F. Towards a therapy for Angelman syndrome by targeting a long non-coding RNA. Nature 2015, 518, 409-412. [CrossRef] [PubMed]

144. Peters, S.U.; Bird, L.M.; Kimonis, V.; Glaze, D.G.; Shinawi, L.M.; Bichell, T.J.; Barbieri-Welge, R.; Nespeca, M.; Anselm, I.; Waisbren, S.; et al. Double-blind therapeutic trial in Angelman syndrome using betaine and folic acid. Am. J. Med. Genet. A 2010, 152a, 1994-2001. [CrossRef] [PubMed]

145. Bird, L.M.; Tan, W.H.; Bacino, C.A.; Peters, S.U.; Skinner, S.A.; Anselm, I.; Barbieri-Welge, R.; Bauer-Carlin, A.; Gentile, J.K.; Glaze, D.G.; et al. A therapeutic trial of pro-methylation dietary supplements in Angelman syndrome. Am. J. Med. Genet. A 2011, 155a, 2956-2963. [CrossRef] 
146. Bailus, B.J.; Pyles, B.; McAlister, M.M.; O'Geen, H.; Lockwood, S.H.; Adams, A.N.; Nguyen, J.T.; Yu, A.; Berman, R.F.; Segal, D.J. Protein Delivery of an Artificial Transcription Factor Restores Widespread Ube3a Expression in an Angelman Syndrome Mouse Brain. Mol. Ther. 2016, 24, 548-555. [CrossRef] [PubMed]

147. Weeber, E.J.; Jiang, Y.H.; Elgersma, Y.; Varga, A.W.; Carrasquillo, Y.; Brown, S.E.; Christian, J.M.; Mirnikjoo, B.; Silva, A.; Beaudet, A.L.; et al. Derangements of hippocampal calcium/calmodulin-dependent protein kinase II in a mouse model for Angelman mental retardation syndrome. J. Neurosci. 2003, 23, 2634-2644. [CrossRef]

148. van Woerden, G.M.; Harris, K.D.; Hojjati, M.R.; Gustin, R.M.; Qiu, S.; de Avila Freire, R.; Jiang, Y.H.; Elgersma, Y.; Weeber, E.J. Rescue of neurological deficits in a mouse model for Angelman syndrome by reduction of alphaCaMKII inhibitory phosphorylation. Nat. Neurosci. 2007, 10, 280-282. [CrossRef]

149. Ngo-Anh, T.J.; Bloodgood, B.L.; Lin, M.; Sabatini, B.L.; Maylie, J.; Adelman, J.P. SK channels and NMDA receptors form a Ca2+-mediated feedback loop in dendritic spines. Nat. Neurosci. 2005, 8, 642-649. [CrossRef]

150. Sato, A. mTOR, a Potential Target to Treat Autism Spectrum Disorder. CNS Neurol. Disord Drug Targets 2016, 15, 533-543. [CrossRef]

151. Sun, J.; Baudry, M.; Bi, X. Novel neurobiological roles of UBE3A. Oncotarget 2017, 8, 12548-12549. [CrossRef] [PubMed]

152. Burket, J.A.; Benson, A.D.; Tang, A.H.; Deutsch, S.I. Rapamycin improves sociability in the BTBR T(+)Itpr3(tf)/J mouse model of autism spectrum disorders. Brain Res. Bull. 2014, 100, 70-75. [CrossRef] [PubMed]

153. Wang, Y.; Liu, X.; Zhou, L.; Duong, D.; Bhuripanyo, K.; Zhao, B.; Zhou, H.; Liu, R.; Bi, Y.; Kiyokawa, H.; et al. Identifying the ubiquitination targets of E6AP by orthogonal ubiquitin transfer. Nat. Commun. 2017, 8, 2232. [CrossRef] [PubMed]

154. Robak, T.; Huang, H.; Jin, J.; Zhu, J.; Liu, T.; Samoilova, O.; Pylypenko, H.; Verhoef, G.; Siritanaratkul, N.; Osmanov, E.; et al. Bortezomib-based therapy for newly diagnosed mantle-cell lymphoma. N. Engl. J. Med. 2015, 372, 944-953. [CrossRef]

155. Lonial, S.; Weiss, B.M.; Usmani, S.Z.; Singhal, S.; Chari, A.; Bahlis, N.J.; Belch, A.; Krishnan, A.; Vescio, R.A.; Mateos, M.V.; et al. Daratumumab monotherapy in patients with treatment-refractory multiple myeloma (SIRIUS): An open-label, randomised, phase 2 trial. Lancet 2016, 387, 1551-1560. [CrossRef]

156. Landgren, O.; Sonneveld, P.; Jakubowiak, A.; Mohty, M.; Iskander, K.S.; Mezzi, K.; Siegel, D.S. Carfilzomib with immunomodulatory drugs for the treatment of newly diagnosed multiple myeloma. Leukemia 2019, 33, 2127-2143. [CrossRef]

157. Zang, Y.; Thomas, S.M.; Chan, E.T.; Kirk, C.J.; Freilino, M.L.; DeLancey, H.M.; Grandis, J.R.; Li, C.; Johnson, D.E. Carfilzomib and ONX 0912 inhibit cell survival and tumor growth of head and neck cancer and their activities are enhanced by suppression of Mcl-1 or autophagy. Clin. Cancer Res. 2012, 18, 5639-5649. [CrossRef]

158. Moon, S.; Lee, B.H. Chemically Induced Cellular Proteolysis: An Emerging Therapeutic Strategy for Undruggable Targets. Mol. Cells 2018, 41, 933-942. [CrossRef]

159. Okuhira, K.; Ohoka, N.; Sai, K.; Nishimaki-Mogami, T.; Itoh, Y.; Ishikawa, M.; Hashimoto, Y.; Naito, M. Specific degradation of CRABP-II via cIAP1-mediated ubiquitylation induced by hybrid molecules that crosslink cIAP1 and the target protein. FEBS Lett. 2011, 585, 1147-1152. [CrossRef]

160. Ohoka, N.; Okuhira, K.; Ito, M.; Nagai, K.; Shibata, N.; Hattori, T.; Ujikawa, O.; Shimokawa, K.; Sano, O.; Koyama, R.; et al. In Vivo Knockdown of Pathogenic Proteins via Specific and Nongenetic Inhibitor of Apoptosis Protein (IAP)-dependent Protein Erasers (SNIPERs). J. Biol. Chem. 2017, 292, 4556-4570. [CrossRef]

(C) 2020 by the authors. Licensee MDPI, Basel, Switzerland. This article is an open access article distributed under the terms and conditions of the Creative Commons Attribution (CC BY) license (http://creativecommons.org/licenses/by/4.0/). 